\title{
Pair-rule segmentation genes regulate the expression of the homeotic selector gene, Deformed
}

\author{
Thomas Jack, Michael Regulski, and William McGinnis \\ Departments of Molecular Biophysics and Biochemistry, and Biology, Yale University, New Haven, Connecticut 06511 USA
}

\begin{abstract}
Using antibodies directed against the protein produced from the homeotic selector locus Deformed (Dfd), we have determined its spatial distribution both in wild-type embryos and in embryos mutant for a variety of segmentation genes. The $D f d$ protein is first detectable in a single circumferential stripe of about six cells at the cellular blastoderm stage. During gastrulation and at later stages its principal domain of epidermal expression is in the mandibular and maxillary segments of the embryonic head. Though not strongly altered by mutations in most of the zygotic gap genes and other selector genes, the pattern of $D f d$ expression is dramatically altered in mutants for eight of the nine pair-rule segmentation genes. The precise delimitation of $D f d$ expression can be largely accounted for by hierarchical and combinatorial effects of segmentation gene activities. In addition, the control of $D f d$ expression is also regulated by at least two other factors that are differentially active on both the anterior-posterior and dorsal-ventral axes. Our results support the idea that a hierarchy of homeobox regulatory genes plays a key role in dividing and determining the Drosophila body pattern.
\end{abstract}

[Key Words: Drosophila; development; homeobox; homeotic genes; Deformed gene expression]

Received February 5, 1988; revised version accepted April 12, 1988.

In Drosophila the eventual determination of segmental identity is dependent upon stable, localized expression of homeotic selector genes (Garcia-Bellido 1977; Lewis 1978; Struhl 1982; Akam 1983; Levine et al. 1983). Precise spatial limits on the expression of homeotic genes is important to both the form and function of the fruit fly because ectopic expression can trigger homeotic transformations that often result in embryonic or larval death (Lewis 1978; Hafen et al. 1983; Schneuwly et al. 1987). Although the details are still obscure, the restricted spatial patterns of homeotic expression appear to be the focus of a hierarchy of genes that successively refine positional information in the early embryo (reviewed in Akam 1987; Scott and Carroll 1987). A detailed description of the regulatory interactions among the different levels of the hierarchy will be necessary in order to guide and interpret a molecular description of Drosophila pattern formation.

Establishment of the initial limits on homeotic selector/gene expression is likely to be under the control of the zygotically active gap and pair-rule segmentation genes (Nüsslein-Volhard and Wieschaus 1980). Both gap and pair-rule genes begin to be expressed during the period from 2 to $3 \mathrm{hr}$ of development, just prior to and during the establishment of selector expression boundaries (Hafen et al. 1984a; Knipple et al. 1985). The mutant phenotypes of gap genes indicate that they subdivide the embryonic space into large blocks of segments. For example, mutants in the gap gene hunchback $(h b)$ are missing posterior head segments, all three thoracic segments, and parts of the seventh and eighth abdominal segments (A7 and A8) (Lehmann and Nüsslein-Volhard 1987). At least part of this phenotype is due to the resulting disruptions in the expression limits of the homeotic genes Sex Combs Reduced (Scr), Antennapedia $(A n t p)$, and Ultrabithorax (Ubx). The normal domain of Scr expression extends posteriorly into the first thoracic segment, while in $h b$ mutants several rows of cells in this region lack $S c r$ protein (Riley et al. 1987). Antp transcripts are not expressed in their normal parasegment 4 domain (Harding and Levine 1988), and $U b x$ expression expands both anteriorly and posteriorly in $h b$ mutants (White and Lehmann 1986). The extent to which these regulatory interactions are direct or indirect is as yet unclear.

A second group of segmentation genes, the pair-rule class, partition the embryo into two segment-width blocks. For example, mutants in fushi tarazu (ftz) are missing alternate segment boundaries, starting at the maxillary-labial border and continuing posteriorly to the border separating the eighth and ninth abdominal segments (A8 and A9) (Wakimoto and Kaufman 1981). In addition to its effect on segment boundaries, $f t z$ has been reported to be necessary for the proper amount of some downstream selector expression, specifically that from the $S c r, A n t p$, and $U b x$ loci. For example, in ftz mutants fewer cells express the $S c r$ protein, and the transcript levels of $S c r, A n t p$, and $U b x$ never attain their early 
peaks of abundance in parasegments 2,4 , and 6 (PS2, PS4, PS6), respectively (Ingham and Martinez-Arias 1986; Riley et al. 1987; Martinez-Arias and White 1988).

The precise role of the plethora of segmentation genes in the initiation of homeotic gene expression is currently unclear. Given the lack of data, current models are necessarily vague about the direct regulatory contributions from hierarchical versus combinatorial interactions (Gergen et al. 1986; Ingham and Martinez-Arias 1986; Scott and O'Farrell 1986). In a strict hierarchical model the maternal-effect genes activate the gap genes which in turn activate the pair-rule genes; in such a simple hierarchical model the end result of this serial cascade is the activation of a single product that activates or represses a homeotic gene. Alternatively, in an extreme combinatorial model the various gap and pairrule products persist together in the same cells and a combination of factors is required to directly activate or repress a given downstream homeotic gene. Obviously, combinatorial and hierarchical regulatory interactions are not mutually exclusive, and the actual regulatory network will almost certainly involve both. Currently it is known that hierarchy plays an important role as evidenced by the cross-regulation among both pair-rule and gap genes as well as the alterations of pair-rule patterns in gap mutants (Carroll and Scott 1986; Harding et al. 1986; Howard and Ingham 1986; Jackle et al. 1986; DiNardo and O'Farrell 1987; Frasch and Levine 1987).
There is as yet no specific combinatorial code defined that is sufficient to direct the spatial activation of any gene in the early developmental hierarchy.

$D f d$, a homeotic selector gene of the Antennapedia complex (ANT-C), specifies the identity of many of the head structures which derive from the mandibular and maxillary segments (Merrill et al. 1987; Regulski et al. 1987). One major transcript class is encoded by this locus, and this transcript accumulates in an circumferential, anterior stripe just prior to the cellularization of the blastoderm embryo, at about $2.75 \mathrm{hr}$ after egg laying (AEL) (Chadwick and McGinnis 1987; Martinez-Arias et al. 1987). In addition, during larval stages $D f d$ is expressed in a specific region of the eye-antennal imaginal disc, and is required in this region of the disc for proper adult head development (Merrill et al. 1987; R. Chadwick, pers. comm.).

The early and highly restricted nature of its expression pattern make $D f d$ an advantageous gene for studying the regulatory effects of gap and segmentation genes on selector gene expression. We have developed antiserum directed against the $D f d$ protein and used it to stain whole-mount embryos from both wild-type and mutant Drosophila embryos. Analysis of a variety of mutant embryos indicates that the $D f d$ pattern is dramatically altered in almost all the mutants of the pair-rule class, but is only mildly affected or unchanged in mutants of the zygotic gap and homeotic selector classes that we
Figure 1. Antibodies against full-length $D f d$ protein. (a) Plasmid pARDfd used for the production of antibodies to $D f d$. A 1.8-kb Sacl/ $E c o R V$ fragment from the $D f d$ cDNA plasmid pcDfd4l (Regulski et al. 1987) was cloned into the NdeI site of the parental T7 expression vector pAR3040 which was cut with BamHI, filled in, and then cut with NdeI. In order to get the full-length $D f d$ protein cloned into pAR3040, an 8-base oligonucleotide (insert above) was cloned between the NdeI site of pAR3040 and the SacI site of Dfd. The location of the $T 7 \phi 10$ promoter and $T \phi$ terminator sequences are indicated by black boxes, the $D f d$ open reading frame $\{O R F\}$ by a cross-hatched box. The prokaryotic ShineDalgarno $(S h-D)$ sequence is indicated (Shine and Dalgarno 1974; Steitz and Jakes 1975). b) SDS - polyacrylamide gel and Western transfer of extracts of cells containing $D f d$ expression plasmids. (Lane 1) Total extract from IPTG-induced cells containing pAR3040. (Lane 2) Total extract from cells containing pARDfd before induction with IPTG. (Lane 3) Total extract from cells containing pARDfd after induction with IPTG. (Lanes 4-6) Replicate Western blot transfers of lanes $1-3$, respectively, after staining with $1: 1000$ dilution of whole serum from a rabbit immunized with the T7-induced, fulllength $D f d$ protein. Size markers $(M) \mathrm{kD}$ are indicated at the left. a
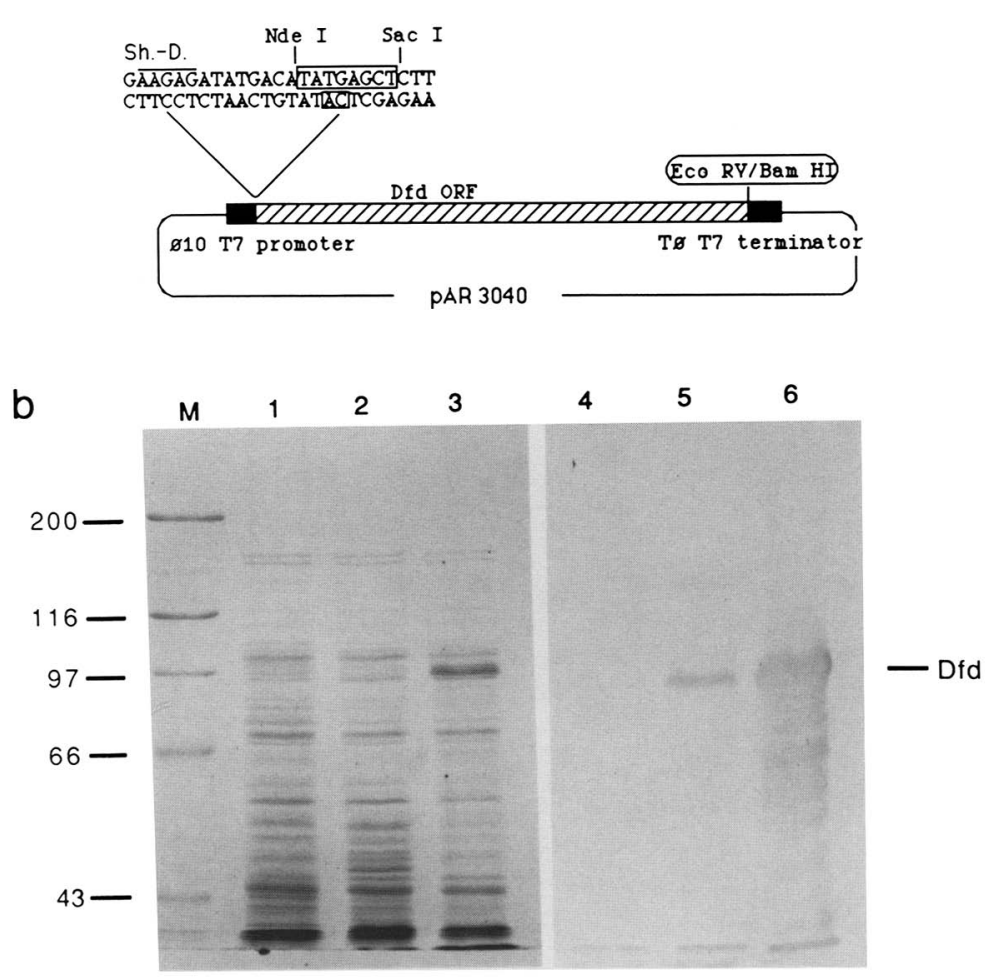
have analyzed. In addition to the regulatory effects of the pair-rule genes, our results suggest that the proper expression of $D f d$ is dependent on the presence of at least two other factors that are differentially distributed along both the anterior-posterior and dorsal-ventral axes.

\section{Results}

\section{Dfd protein expression and production of antibodies}

The $D f d$ gene lies in the ANT-C between $S c r$ and bicoid (bcd) (Merrill et al. 1987). Previous work (Regulski et al. 1985, 1987; Chadwick and McGinnis 1987) has shown that the sole major transcript from the $D f d$ locus contains an open reading frame that encodes a postulated 586 amino acid protein. Some of the distinctive features of this protein include a homeodomain similar in sequence to that of other homeotic selectors, as well as repetitive monotonic amino acid tracts like polyglutamine and polyasparagine. To obtain large amounts of $D f d$ protein we used the T7 expression system (Studier and Moffatt 1986). In the construction of the expression plasmid, pARDfd (Fig. la), a 1.8-kb fragment from the cDNA plasmid pcDfd4l containing the entire open reading frame of $D f d$ was cloned into the $\mathrm{T} 7$ expression vector pAR3040. Upon induction amounts in the range of $5-10 \mathrm{mg} / \mathrm{l}$ of full-length $D f d$ protein are obtained. On SDS-polyacrylamide gels the $D f d$ protein migrates with an apparent molecular weight of $90-95-\mathrm{kD}$. (Fig. 1b), much higher than the expected molecular weight of 63.5 $\mathrm{kD}$ based upon conceptual translation.

For antibody production, the $D f d$ protein was partially purified as described in Materials and methods and then used to immunize rabbits. After a single boost, serum was successfully used to stain whole-mount embryos. To reduce background staining, the serum was immunoabsorbed against 0-2 hr Drosophila embryos. A Western blot using the purified serum (Fig. 1b) shows that the antiserum recognizes only the $D f d$ protein and its degradation products and not Escherichia coli proteins.

\section{Dfd protein localization in wild-type embryos}

The $D f d$ protein distribution was determined by staining whole-mount embryos with secondary antibodies linked to horseradish peroxidase (HRP). In order to show that the signals visualized on whole-mount embryos are due to $D f d$, we stained $D f d$ null mutant embryos $D f d^{R \times 1} / \mathrm{DF}(3 \mathrm{R}) S c r$ (Hazelrigg and Kaufman 1983; Regulski et al. 1987), and obtained no detectable signals (data not shown).

The $D f d$ protein is first detectable at the cellular blastoderm stage, approximately $3 \mathrm{hr}$ AEL (Fig. $2 \mathrm{a}$ and b). At this stage $D f d$ is expressed at low levels in a stripe of about six cells that encircle the embryo. The protein in this initial stripe of cells is not solely localized in the nucleus, as it is at later stages. Early in gastrulation the cells that express $D f d$ invaginate to form the cephalic furrow. As germ band extension commences, cells within the cephalic furrow begin to proliferate /CamposOrtega and Hartenstein 1985), increasing the depth of the furrow and the total number of $D f d$-expressing cells. Most of these cells reemerge on the exterior surface of the embryo as the cephalic furrow retracts. After the emergence of the ventralmost cells from the cephalic furrow, $D f d$ expression spreads along the ventral midline while remaining more restricted dorsally (Fig. 2c). At this stage it is clear that the $D f d$ protein, like other homeodomain proteins, is localized in the nucleus.

Before the germ band is fully extended along the dorsal surface, prior to the first signs of metamerism, a differential posterior border of $D f d$ expression develops in lateral and ventral positions (Fig. 2d). Laterally the posterior boundary of $D f d$ expression is two or three cells farther posterior than the boundary is ventrally (Fig. 2e). This difference appears to arise from new expression of $D f d$ in the cells that comprise the lateral offset, although migration of previously expressing cells has not been ruled out. At this stage, (about $4.5 \mathrm{hr}$ AEL) a region 12 to 14 cell diameters in length expresses $D f d$ along the ventral midline, including cells of parasegments 0 and 1 (PSO and PS1) as well as some cells anterior to parasegment 0 . Laterally there are fewer $D f d$-expressing cells, five to seven rows of cells posterior to the disappearing cephalic furrow, and one to three rows of cells anterior to the furrow. The morphological boundaries that arise immediately thereafter indicate that the lateral expression outlines the posterior boundary of the future maxillary segment, while the ventral posterior boundary corresponds to the posterior boundary of parasegement 1 (Fig. 2d). The parasegmental position of the posterior boundary in these ventral cells has been confirmed by double labeling embryos from a transformant strain containing $\beta$-galactosidase under the control of the $f t z$ promoter. At the cellular blastoderm stage the anterior boundary of the first $f t z$ stripe and the posterior boundary of $D f d$ directly border one another at all dorsal-ventral positions, but do not overlap. In older embryos (5 hr AEL), the posterior boundary of $D f d$ expression in ventral cells abuts the anterior limit of $f t z$ expression, establishing that this boundary is the PS1PS2 boundary (data not shown).

When the germ band is fully extended, the first signs of metamerism are visible as the parasegmental grooves form along the ventral midline (Martinez-Arias and Lawrence 1985) and the tracheal pits invaginate laterally throughout the thoracic and abdominal segments. Overt signs of segmentation occur first in the head, with the appearance of the gnathal segment boundaries. The $D f d$ protein at this stage (Fig. 2f) is largely confined to the maxillary and mandibular segments laterally and parasegments 0 and 1 ventrally. In addition there is ventral expression anterior to the mandibular segment just posterior to the stomodeal opening, in the hypopharyngeal lobe. The hypopharyngeal labeling is transient; during germ band retraction these cells cease accumulating detectable $D f d$ protein. A reduction in the number of epidermal cells expressing $D f d$ is also seen in both the man- 


\section{Jack et al.}

dibular and maxillary segments. Only cells in the posterior half of the mandibular segment continue to express $D f d$ as the germ band retracts. In the maxillary segment the cells in anterior and lateral positions stop expressing detectable levels of $D f d$. The cells at the posterior border of the maxillary segment continue to express $D f d$ and appear to accumulate relatively high levels as judged by staining intensity (Fig. $2 \mathrm{~g}$ and $2 \mathrm{~h}$ ). Also at this stage, $D f d$ expression is visible on the dorsal surface in one or two rows of cells in the anterior portion of the dorsal ridge (Fig. 2h) (Jurgens et al. 1986).

\section{Negative regulation of Dfd}

$D f d$ is a good marker for the regulative effect of genes

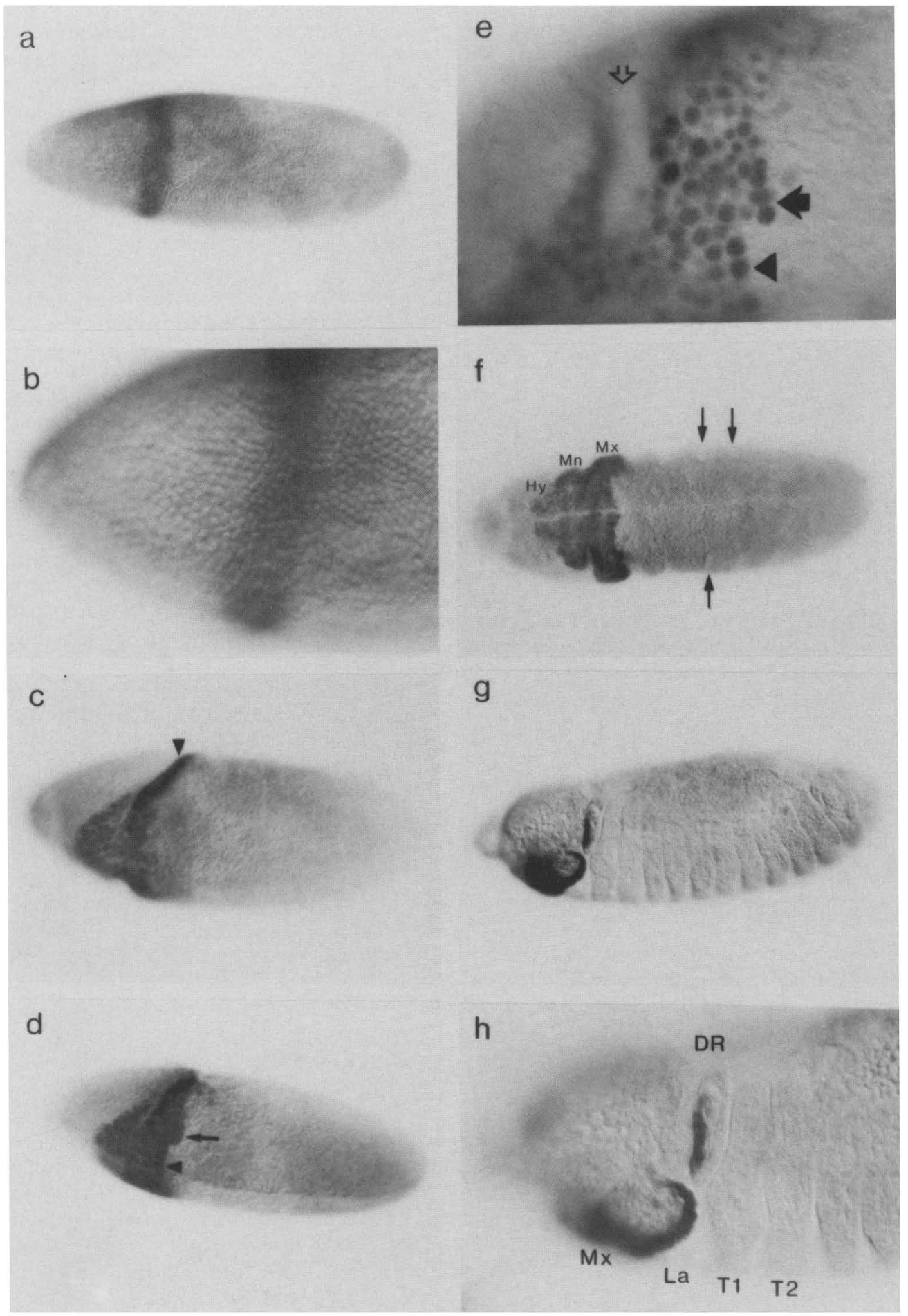

Figure 2. (See facing page for legend.) 
expressed earlier in development for two key reasons. First, the $D f d$ protein is detected considerably earlier than the proteins of the other homeotic selector genes. The $S c r, A n t p$, and $U b x$ proteins are not visible until the extended germ band stage (White and Wilcox 1984, 1985; Beachy et al. 1985; Carroll et al. 1986; Wirz et al. 1986; White and Lehmann 1986; Mahaffey and Kaufman 1987; Riley et al. 1987), between 4 and $4.5 \mathrm{hr}$ AEL, while $D f d$ can be detected at the cellular blastoderm stage, between 2.75 and $3 \mathrm{hr}$ AEL. Second, $D f d$ is expressed in a contiguous block of cells, unlike Antp and $U b x$ which are found expressed periodically in groups of cells of many segments. With expression confined to a single block of cells, changes in pattern are easier to detect.

We detect normal $D f d$ expression patterns in three of the four zygotic gap mutants that we tested $\langle h b|$, knirps $(k n)$, and giant (gt). In $\mathrm{Kr}$ (Krüppel) mutant embryos, we observe a slight increase in the number of $D f d$-expressing cells in both ventral and lateral positions, but this increased expression affects the appearance of neither the anterior nor posterior boundaries of the $D f d$ pattern (data not shown). In addition, a variety of homeotic selector mutations tested $\left[\mathrm{Scr}^{-} ; \mathrm{Scr}^{-} \& A n t p^{-}\right.$; $\mathrm{Scr}^{-}$\& Antp- \& bithorax complex ${ }^{-}$(BX-C) (Struhl 1983)] exhibit normal $D f d$ expression patterns (data not shown).

In sharp contrast, mutations in eight pair-rule genes yield unique and obvious changes in the wild-type $D f d$ pattern; the ninth, sloppy-paired (slp), exhibits little or no change. In mutants for three of the pair-rule loci, $f t z$, odd-skipped (odd), and hairy $(h)$, there are more $D f d$-expressing cells when compared to wild-type. These three genes, whose effects are among those described in detail below, appear to formally act as negative regulators of $D f d$ expression.

fushi tarazu (ftz) Strong $f t z$ mutants exhibit the classic pair-rule phenotype; alternate segment boundaries are missing in $f t z$ mutants. The first segment boundary that is missing in $\mathrm{ftz}^{-}$is the boundary between the maxillary and labial segments (Wakimoto et al. 1984), and the anterior boundary of $f t z$ expression coincides with the parasegment 1 -parasegment 2 boundary, midway through the maxillary segment (Carroll and Scott 1985). (For a summary of all pair-rule expression/mutant phenotype patterns, see Fig. 3). This parasegmental boundary, which in wild-type is the ventral posterior limit of $D f d$ expression, is the site of ectopic expression of $D f d$ in $f t z$ mutants. Figure $4 \mathrm{~b}$ shows a ventral view of an $f t z^{-} \mathrm{em}-$ bryo. At this stage the parasegmental grooves are just barely visible and $D f d$ is expressed in the first double parasegment that results from the fusion of parasegments 1 and 2. Normally at this stage the posterior border of $D f d$ expression is about one-half segment further posterior in lateral positions than in the ventralmost cells (Fig. 4a). In $\mathrm{ftz}^{-}$the converse is true; more cells express $D f d$ along the ventral midline than in wildtype. In some embryos, the ectopic $D f d$-expressing cells spread ventrally almost to the parasegmental groove separating the fused, double-width parasegments resulting from the fusion of parasegments 1 and 2, and parasegments 3 and 4 (Fig. $4 \mathrm{~b}$ ). In most $f t z$ mutant embryos fewer cells express $D f d$ in posterior-lateral positions than in wild-type; this is likely due to the lack of the expression of engrailed (en) at this position in $\mathrm{ftz} \mathrm{mu}$ tants (Howard and Ingham 1986; DiNardo and O'Farrell 1987), as en appears to function as a positive regulator of $D f d$ (see following). In addition, the smooth boundary of expression that is present in wild-type at the maxillarylabial border is replaced by an uneven boundary that reflects both the patchy expression and uneven levels of $D f d$ expression as judged by staining intensity (Fig. $4 \mathrm{~b}, \mathrm{c}$ ). In general the $D f d$ expression pattern in $f t z$ mutants is more variable laterally than ventrally, in some embryos only two or three rows of cells posterior to the parasegment 0 -parasegment 1 border express $D f d$ while in other embryos there are five or six rows that express in lateral positions. Unlike the dramatic change in $D f d$ expression seen in $f t z$ mutants at germ band extension, the changes in the $D f d$ pattern at the cellular blastoderm

Figure 2. Localization of $D f d$ protein in wild-type embryos. Whole-mount embryos were stained as in Materials and methods. In all panels the anterior end of the embryo is to the left. (a) Wild-type embryo at late cleavage stage 14 (Zalokar and Erk 1976; Foe and Alberts 1983). Dfd expression is confined to a single circumferential band of cells. (b) Close-up of an embryo at the cellular blastoderm stage reveals that $D f d$ protein accumulates in a stripe of approximately 6 cells. $(c)$ Lateral view of an embryo in the early stages of germ band extension, approximately $3.5 \mathrm{hr}$ AEL. $D f d$ expression at this stage begins to spread in ventral aspects of the embryo, but remains in a narrow band dorsally, with some $D f d$-expressing cells inside the disappearing cephalic furrow (arrowhead). (d) Ventrolateral view of a germ band extended embryo at $4.5 \mathrm{hr}$ AEL. At this stage the posterior boundary of $D f d$ respects segmental boundaries in lateral cells and parasegmental boundaries along the ventral midline. Dfd is expressed in the precursors of the mandibular and maxillary segments at this stage. The $D f d$ staining is clearly nuclear at this stage. (Arrowhead) Parasegment $1-2$ boundary. (Arrow) Maxillary segment posterior boundary. $(e)$ Close-up of the posterior boundary of $D f d$ expression in a germ band extended embryo. Here the posterior boundary is extended by two rows of cells in lateral positions, respecting the maxillary-labial segment boundary. (Arrowhead) Parasegment 1-2 boundary. (Solid arrow) Maxillary segment posterior boundary. (Open arrow) Position of the cephalic furrow. (f) Ventral view of an embryo with the germ band fully extended, about $6 \mathrm{hr}$ AEL. At this stage the tracheal pits (arrows) and the parasegmental grooves are visible. $D f d$ is expressed in the maxillary $(M x)$ and the mandibular $(M n)$ segments which are visible laterally and in parasegments 0 and 1 ventrally. Also at this stage there is expression of $D f d$ in cells anterior to the mandibular segment in the hypopharyngeal $(\mathrm{Hy})$ lobe. $(g)$ Lateral view of an embryo undergoing germ band retraction (10 hr AEL). At this stage $D f d$ expression disappears in the anterior-lateral cells of the maxillary segment. (h) Close-up of the embryo in $(g)$. The strong expression of $D f d$ in the cells of the maxillary segment $(M x)$ which border the labial lobe $(L a)$ is clearly visible when compared with the anterior-lateral cells of the maxillary segment which no longer express $D f d$. The expression of $D f d$ in the dorsal ridge $(D R)$ is confined to one or two rows of cells in the anterior portion bordering the optic lobe. 


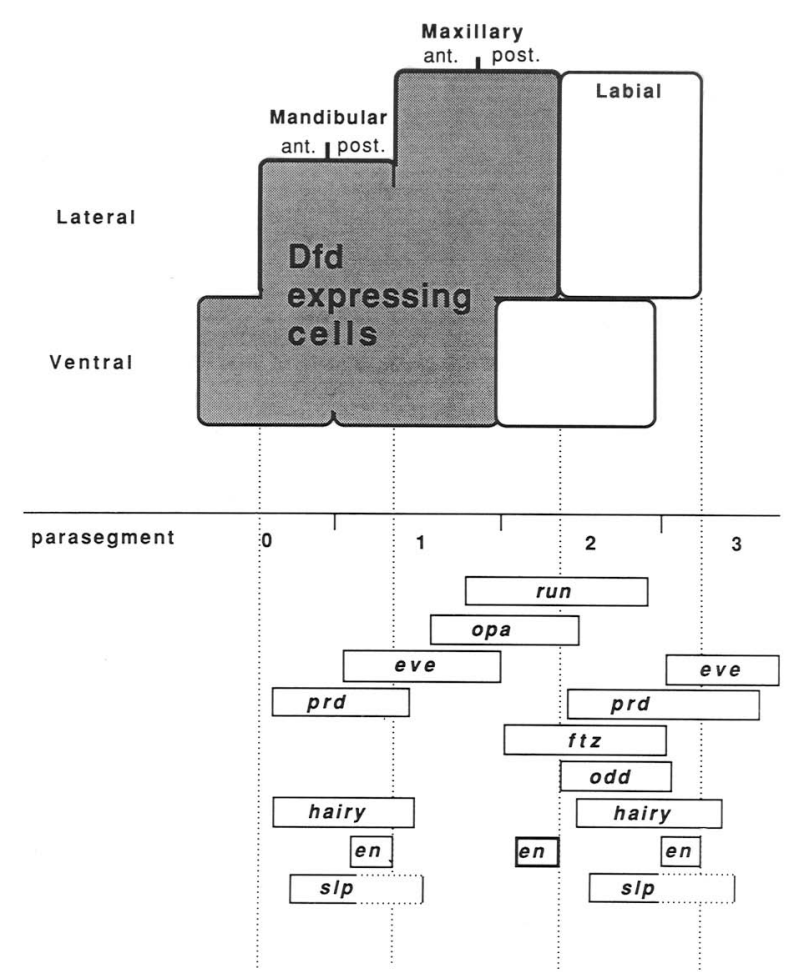

Figure 3. Summary of the expression patterns of Dfd and pair-rule genes. The top half of the figure is a schematic of the gnathal segments showing the limits of Dfd expression (shaded) in wild-type embryos at germ band extension $(5 \mathrm{hr}$ $\mathrm{AEL})$. At this stage, the major domains of expression are in the mandibular and maxillary segments laterally and in parasegments 0 and 1 ventrally. The bottom half of the figure is based on both the regions of expression and the mutant phenotypes of the pair-rule genes. Several of the pair-rule genes have been cloned, including prd, eve, $h$, en, and $f t z$; for these genes the specified regions of expression are based on molecular data. For run, opa, odd, and slp the regions of expression are based on the regions of the embryo that are phenotypically disrupted in $\mathrm{mu}$ tants.

stage are visualized as a small increase in the width of the initial $D f d$ expression stripe from the normal five or six cells to seven cells in $\mathrm{ftz}$ mutants (cf., Fig. $5 \mathrm{~d}$,f).

odd-skipped (odd) The terminal phenotype of odd mutants is not the typical pair-rule phenotype as the segmental deletions in odd mutants span less than a complete segment (Nüsslein-Volhard et al. 1985; Gergen et al. 1986). The odd- phenotype results from the deletion of the naked cuticle in the anterior compartment and the majority of the denticle band of each odd numbered abdominal segment along with a mirror image duplication of the remaining anteriormost rows of the denticle band. The duplication is associated with an expansion of the expression domain of the en protein (DiNardo and O'Farrell 1987). By extrapolating into the head, the frame of segmental deletions found in the thorax, and abdomen, it seems likely that in odd mutants the anterior portion of the labial lobe is the most anterior segmental anlagen affected (Fig. 3).

In contrast to $f t z$ mutants, it is the lateral posterior border of the $D f d$ expression pattern that is strongly altered in $o d d^{-}$. In wild-type embryos between five and seven rows of cells posterior to the cephalic furrow express $D f d$ at five hours of development (Figs. 6a, 2e). In odd ${ }^{-}$, eight to ten rows of cells express $D f d$ in this position. The ectopic expression in odd is most easily visu-

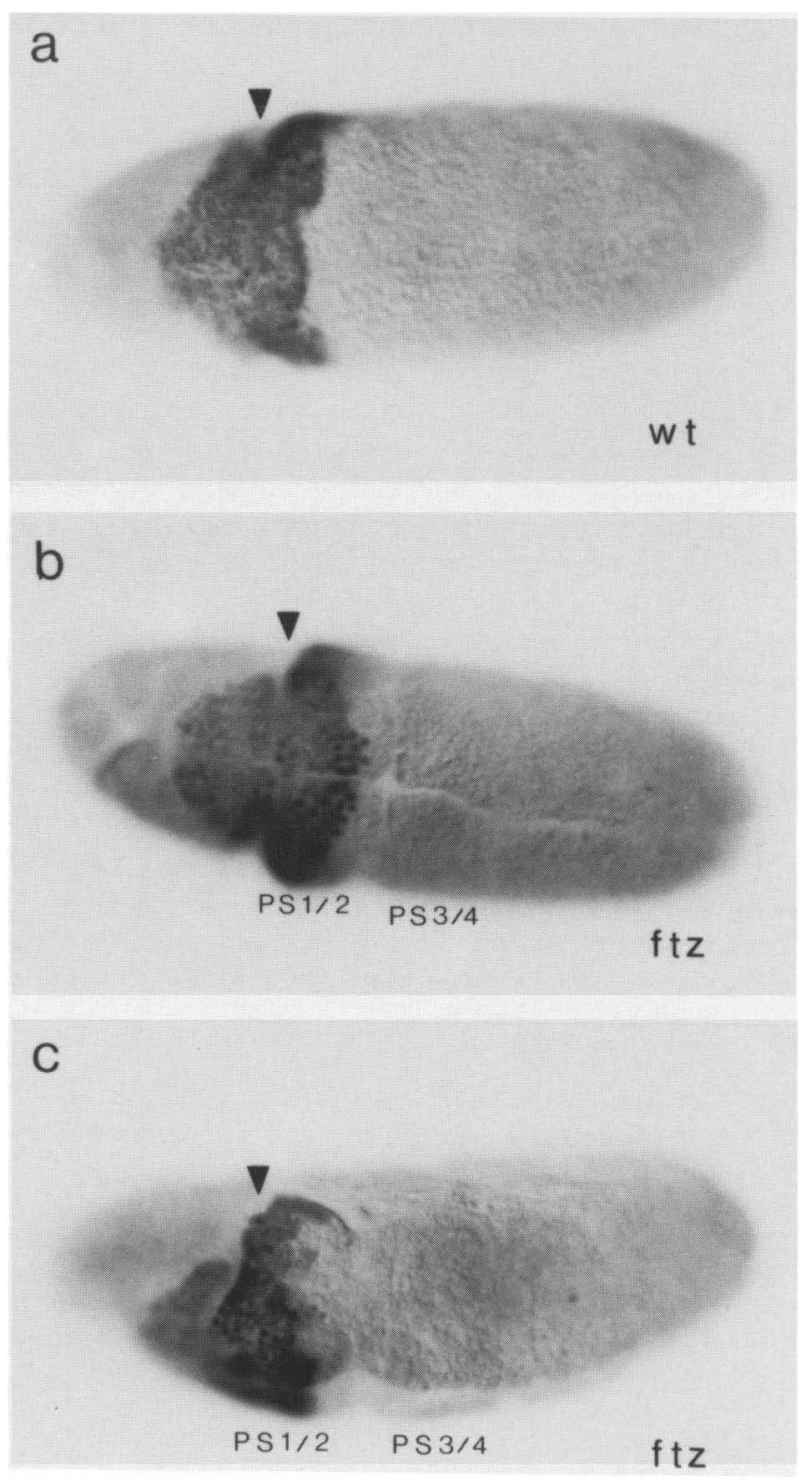

Figure 4. Expression of $D f d$ in $f t z$ mutants. In all panels the anterior end of the embryo is to the left and the arrowhead marks the position of the cephalic furrow. (a) Ventral view of $D f d$ antibody staining of a wild-type embryo at germ band extension. Note that $D f d$ expression at the posterior border extends farther laterally than ventrally. (b) Ventral view of a $f t$ embryo at the same stage as in $a$. Here $D f d$ is misexpressed in ventral cells that would normally be included in parasegment 2 . The fused parasegments 1 and 2 (PS1/2), and 3 and 4 (PS3/4) are indicated. $(c)$ Ventrolateral view of a $\mathrm{ftz}$ mutant embryo at a slightly later stage than $b$. Again note the increased number of $D f d$-expressing cells along the ventral midline and the slight reduction in number and the patchy nature of $D f d$-expressing cells in lateral aspects. The fused parasegments 1 and 2 (PS1/2), and 3 and $4(P S 3 / 4)$ are indicated. 
Table 1. Dfd protein expression in homeotic and segmentation mutants

\begin{tabular}{|c|c|c|}
\hline Gene class locus/allele & Larval phenotypes & Effect on $D f d$ expression \\
\hline \multicolumn{3}{|l|}{ Zygotic gap } \\
\hline hunchback $h b^{14 F 21} h b^{7 L 06}$ & $\begin{array}{l}\text { labial and thoracic segments missing, defects } A 7 \\
\text { and } A 8\end{array}$ & no effect \\
\hline giant $g t^{V A 82}$ & $\begin{array}{l}\text { labial segment and anterior head structures } \\
\text { missing }\end{array}$ & no effect \\
\hline Krupple $K r^{2}$ & $\begin{array}{l}\text { thoracic and A1-A5 segments missing, A6 } \\
\text { duplicated }\end{array}$ & slight increase in the number of expressing cells \\
\hline knirps $k n^{5 F 107}$ & abdominal segments missing & no effect \\
\hline \multicolumn{3}{|l|}{ Pair-rule } \\
\hline hairy $h^{k 1}$ & even-numbered denticle bands missing & lateral patch of expression at labial-Tl boundary \\
\hline runt run ${ }^{p V 1}$ & $\begin{array}{l}\text { odd-numbered denticle bands missing, defects } \\
\text { A4 and A5 }\end{array}$ & $\begin{array}{l}\text { reduced expression laterally at posterior } \\
\text { boundary }\end{array}$ \\
\hline even-skipped ever13 & unsegmented, lawn of denticles & $\begin{array}{l}\text { central region missing both laterally and } \\
\text { ventrally }\end{array}$ \\
\hline$e v e^{3.77 .17} e v e^{I D 19}$ & even-numbered denticle bands missing & $\begin{array}{l}\text { like } e v e^{r 13} \text { ventrally, lateral expression only } \\
\text { slightly reduced }\end{array}$ \\
\hline $\begin{array}{l}\text { fushi tarazu } f t z^{9 H 34} f t z^{9093} \\
\quad f t z^{\text {w20 }}\end{array}$ & odd-numbered denticle bands missing & $\begin{array}{l}\text { increased expression in parasegment } 2 \text { ventrally, } \\
\text { slightly reduced expression laterally at } \\
\text { posterior boundary }\end{array}$ \\
\hline paired prd $d^{I I B 82}$ & even-numbered denticle bands missing & reduced expression at anterior boundary \\
\hline odd-paired opa ${ }^{5 H 97}$ & odd-numbered denticle bands missing & reduced expression at posterior boundary \\
\hline odd-skipped odd ID36 & odd-numbered denticle bands missing & $\begin{array}{l}\text { increased expression at posterior boundary in } \\
\text { lateral positions }\end{array}$ \\
\hline sloppy-paired slp ${ }^{I I M 105}$ & even-numbered denticle bands missing & no consistent effects \\
\hline engrailed en n $^{I 1 B 86}$ & $\begin{array}{l}\text { defects in posterior compartments of each } \\
\text { segment }\end{array}$ & $\begin{array}{l}\text { reduced expression laterally at posterior } \\
\text { boundary }\end{array}$ \\
\hline $\begin{array}{l}\text { double and triple mutants } \\
\text { prd }^{32.12} \text { odd } d^{I D 36}\end{array}$ & severe segmentation defects & additive: $p r d$ description plus odd description \\
\hline prd $^{32.12}$ odd ${ }^{I D 36} e v e^{I D 19}$ & severe segmentation defects & additive \\
\hline prd ${ }^{11 B 82}$ opa $a^{5 H 97}$ & severe segmentation defects & additive \\
\hline \multicolumn{3}{|l|}{ Homeotic selector } \\
\hline $\begin{array}{l}\text { Deformed } D f d^{R X 1} / D f \\
\quad 3 \mathrm{R}(S c r)\end{array}$ & larval atrium $\rightarrow$ pharynx & no detectable expression \\
\hline $\begin{array}{l}\text { Sex combs reduced } S c r^{C P 1} \\
\text { Scr }{ }^{E W 17} S c r^{E A 68} S c r^{3 A 72}\end{array}$ & $\mathrm{~T} 1 \rightarrow \mathrm{T} 2$, labial $\rightarrow$ maxillary & no effect \\
\hline \multicolumn{3}{|l|}{ double and triple mutants } \\
\hline$S c r^{C 1}$ Antp $p^{N+R C 3}$ & $\mathrm{~T} 3, \mathrm{~T} 2 \rightarrow \mathrm{T} 1$, labial $\rightarrow$ maxillary & no effect \\
\hline $\begin{array}{l}\text { Scr }{ }^{\mathrm{Cl}} \text { Antp }^{\mathrm{Ns}+\mathrm{RC} 3} \text { Dfd } \\
\quad \text { 9 }\end{array}$ & $\mathrm{T} 2-\mathrm{A} 8 \rightarrow \mathrm{T} 1$, labial $\rightarrow$ maxillary & no effect \\
\hline
\end{tabular}

alized by looking at the offset between the parasegmental and segmental boundaries of $D f d$ expression. In wild-type, the lateral expression is offset posteriorly by two to three cells while in odd $d^{-}$(Fig. 6b) the offset is between four and seven cells. The cells that misexpress $D f d$ in odd mutants would normally be included in the labial lobe.

sloppy-paired $\langle s l p\rangle$ The mutant phenotype of slp is not well characterized. In weak alleles the cuticle within a single segment is missing in alternating segments including T2 and the odd-numbered abdominal segments (Fig. 3, Nüsslein-Volhard et al. 1982, 1984). A few of the embryos mutant for slp appear to have a slightly larger $D f d$ expression domain in both lateral and ventral positions, but this effect is variable and subtle and is not fully penetrant (data not shown). The variability could be due to the strength of the $s l p$ allele, which may not be a null.

hairy $(h)$ The segment boundaries that are present in $f t z$ mutants are missing in $h$ mutants (Fig. 3; NüssleinVolhard and Wieschaus 1980). Thus, the first segment boundary missing in $h$ mutants is the mandibular-maxillary boundary (Ingham et al. 1985). In addition, many of the cells of the mandibular and some cells of the anterior maxillary develop abnormally in $h$ mutants.

In $f t z$ and odd mutant embryos the misexpression of $D f d$ is in cells adjacent to the major domain of $D f d$ expression in the mandibular and maxillary segments. In contrast, the sole defect in $h$ mutants involves misexpression in cells that are separate from the major domain of $D f d$ expression. In $\mathrm{h}^{-}$the $D f d$ expression pattern is normal in the mandibular and maxillary segments but a new row of cells expresses $D f d$ in lateral cells approximately at the position of the labial-T1 segment boundary (Fig. 6c). Thus, there are about five or six rows of cells that do not express $D f d$ between the maxillarylabial border and the ectopically expressing row of cells found in $h$ mutants. Most typically the misexpression involves a single row of between four and six cells that 
Jack et al.

Figure 5. Early expression of $D f d$ in $e v e$ and $f t z$ mutants. In all panels the anterior end of the embryo is to the left. Dfd staining of cellular blastoderm stage embryos from $(a, d)$ wild-type, $(b, e) e v e^{r 13}$, and $(c, f) f t z^{w 20}(c, f)$ showing the whole embryo $(a-c)$ and close-ups $(d-f)$. In wildtype embryos $(a, d) D f d$ protein initially appears as a band of from 5 to 6 cells. In eve mutants $(b, e)$, this initial band of expression is narrower, containing about 4 cells while in $f t z$ mutants $(c, f)$ the initial band is broader, about 7 cells wide.
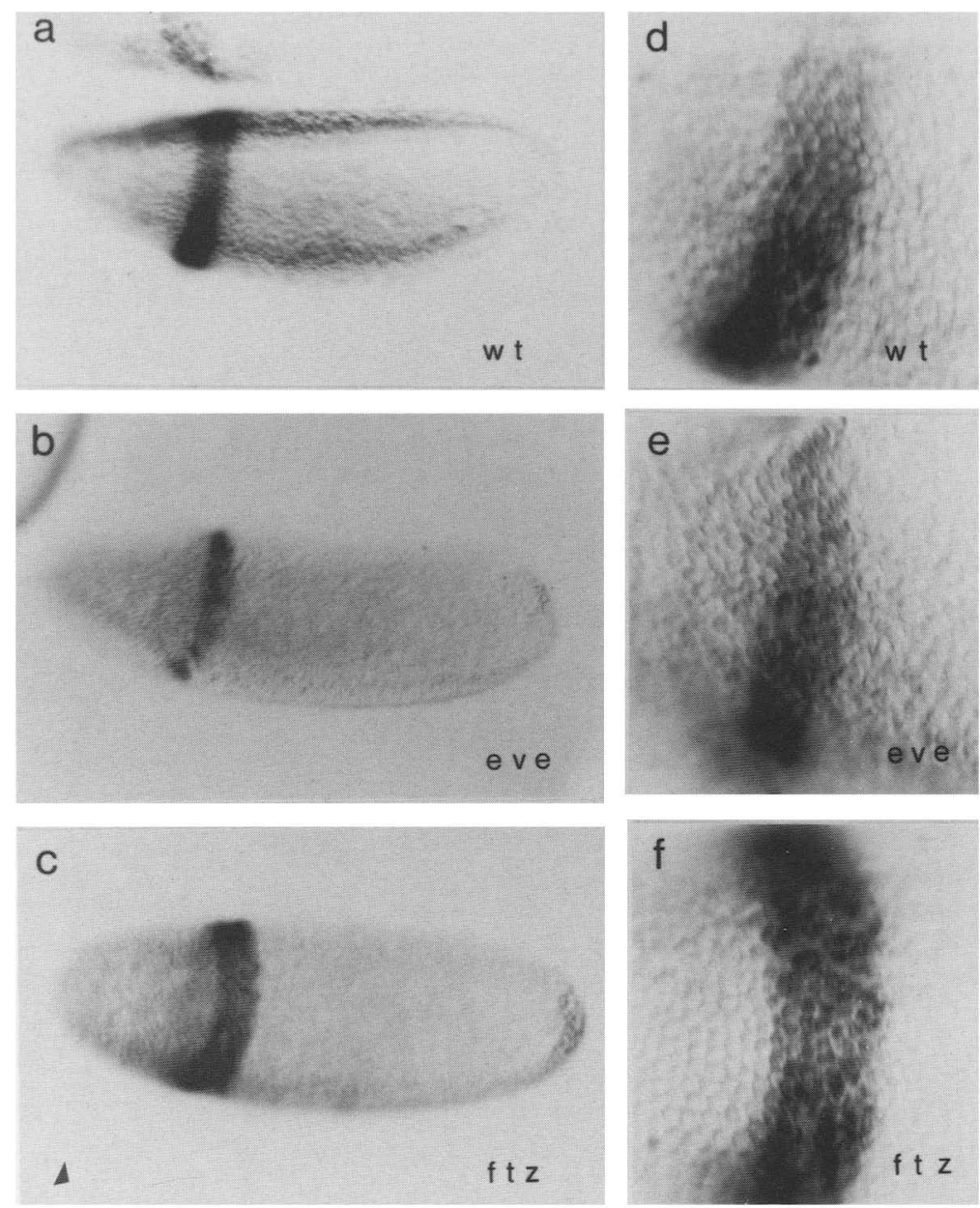

extends ventrally from the lateral midline. Sometimes, instead of a row, there is a clump of five or six expressing cells near the lateral midline. In rare cases the misexpression is found more ventrally, in the middle of the labial segment, usually involving single cells rather than clusters.

\section{Pair-rule genes that positively regulate Dfd}

In mutants for the five pair-rule loci en, odd-paired (opa), runt (run), paired (prd), and even-skipped (eve), there are fewer $D f d$-expressing cells. Of these five genes that formally appear to act as positive regulators; opa, run, and en are necessary in the posterior region of the $D f d$-expression pattern, eve is necessary in the central region, and prd function is necessary for correct expression in the anterior region.

odd-paired (opa) Like odd and slp, the functional domains of opa in the head region are not well characterized. Mutants in opa delete the same segment boundaries as $f t z$, namely thorax 1-thorax 2 , thorax 3-abdomen 1 (T1-T2, T3-A1), etc. (Nüsslein-Volhard et al. 1982; Jurgens et al. 1984). If the frame of opa deletions is the same in the head as in the thorax and abdomen, then the maxillary-labial segment boundary should be missing with the deleted cuticle deriving mostly from the maxillary segment rather than deleting roughly equal numbers of cells from the maxillary and labial segments as in $\mathrm{ftz}$ (Fig. 3).

Of the three genes that regulate $D f d$ expression at the posterior boundary, opa mutants exhibit the most drastic reduction in the number of $D f d$-expressing cells. The extent of the reduction in $D f d$ expression both laterally and ventrally is shown in Figure $7 \mathrm{~b}$. In wild-type embryos between five and seven rows of cells in lateral positions express $D f d$ posterior to the cephalic furrow. In opa mutants, only two or three rows of cells stain with $D f d$ antiserum. Ventrally the reduction is not quite as severe, typically involving a loss of $D f d$ expression in about three rows of cells. In rare embryos a few cells misexpress $D f d$ in lateral, more posterior positions (Fig. $7 \mathrm{~b}$, note arrows |, at locations similar to the misexpression in $h$. This misexpression is sporadic and rarely involves more than four misexpressing cells.

runt (run) The segment boundaries missing in run are the same as those missing in ftz and opa /see Fig. 3; Nüsslein-Volhard and Wieschaus 1980; Gergen and Wieschaus 1986a). The fact that run appears to be involved in the development of fewer maxillary cells than 


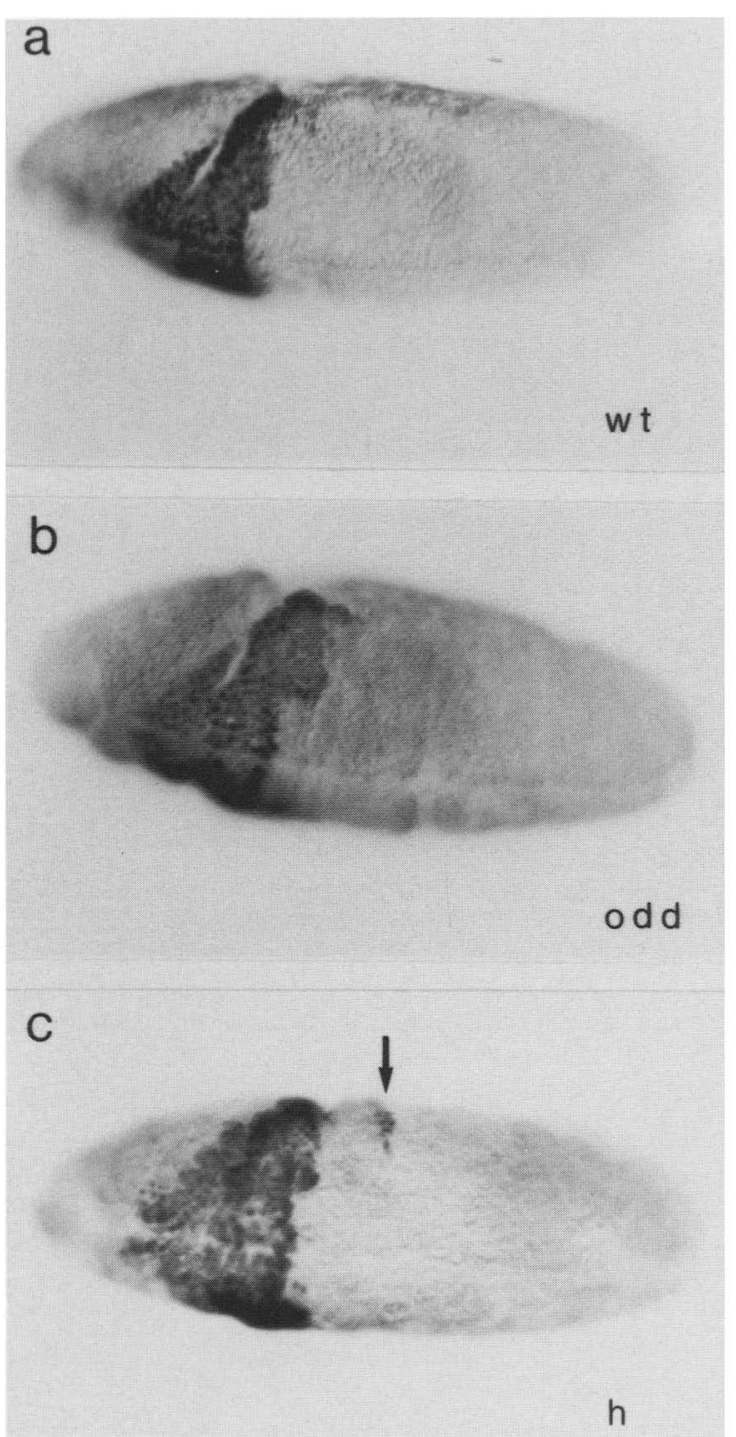

Figure 6. Expression of $D f d$ in odd and $h$ mutants. In all panels the anterior end of the embryo is to the left. $|a|$ Ventrolateral view of a wild-type embryo at germ band extension. $(b)$ Ventrolateral view of an odd- embryo at germ band extension. Note the increase in $D f d$ expression in the lateral cells that comprise the posterior boundary, in the precursors of the labial segment. $D f d$ expression in ventral aspects of the embryo appears normal. $\langle c|$ Ventrolateral view of a $h^{-}$embryo at germ band extension. Note the stripe of ectopic $D f d$-expressing cells (arrow) in posterior and lateral positions at the approximate location of the labial-T1 segment boundary.

opa may explain its less severe effect on the $D f d$ expression pattern. In run mutants (Fig. 7c) the lateral expression of $D f d$ is reduced about as much as in opa but the reduction along the ventral aspect is less severe. Approximately two or three rows of cells stain posterior to the cephalic furrow in lateral positions, a reduction of between three and five rows of cells. Along the ventral midline $D f d$ expression is reduced by at most one row of cells.

engrailed (en) Because the segmental defects in en can occur in all segments, en is often classified as a segment polarity gene rather than as a pair-rule gene. It has been found that $e n$ is necessary for the proper development of the posterior compartment of each segment (Morata and Lawrence 1975; Kornberg 1981). In the absence of en, the signals necessary for the correct formation of segment boundaries are not present, resulting in a fusion of segments. The most anterior stripe of en expression during early stages of germ band extension is in the posterior compartment of the mandibular segment (DiNardo et al. 1985; Kornberg et al. 1985). The second stripe of en expression is in the maxillary segment; in wild-type embryos this stripe is the earliest en stripe to show high level accumulation of the en protein (Fig. 3).

Mutants in en lack $D f d$ expression in the two lateral, posterior rows of cells of the maxillary segment, while expression of $D f d$ in the mandibular segment is normal (Fig. 7d). In the ventralmost cells of the maxillary segment the posterior boundary of $D f d$ expression appears normal. The rows of cells that are not expressing in enare those which make up the lateral offset in wild-type embryos. In later stage wild-type embryos (7 hr AEL) this posterior maxillary region shows the most intense staining for $D f d$. In later stage en- embryos, the maxillary-labial segment boundary does not form, and only cells near the maxillary-mandibular border express $D f d$ (data not shown).

even-skipped (eve) In wild-type embryos the first stripe of eve-expressing cells overlaps the primordia for the mandibular-maxillary segment boundary, and roughly equal numbers of cells express $e v e$ in the primordia for the mandibular and maxillary segments (Fig. 3; MacDonald et al. 1986; Frasch et al. 1987). Embryos containing amorphic eve alleles never exhibit any signs of segmentation; the terminal phenotype is an unsegmented lawn of denticles.

In amorphic $e v e^{-}$embryos (e.g., $e v e^{r 13}$ ) the reduction in the number of $D f d$-expressing cells is visible at the late cellular blastoderm stage, as the initial $D f d$ expression stripe is four or five cells across instead of the five or six cell width that is seen in wild-type embryos (cf., Fig. $5 \mathrm{~d}, \mathrm{e}$ ). At the germ band extension stage, $D f d$ expression is sharply reduced both laterally and along the ventral midline (Fig. 8c). Laterally only two to three rows of cells express $D f d$ whereas normally there are about eight rows of expressing cells at the extended germ band stage. On the ventral aspect, a domain six to eight cells wide expresses $D f d$, while in wild-type embryos there are 12-14 cells that stain in this position. The $D f d$-expressing cells are not always contiguous. In some mutant animals the clusters of expressing cells are separated by a gap of nonexpressing cells. Because the shape of neither the anterior nor the posterior border of $D f d$ expression appears normal, it is difficult to know with certainty from which segmental primordia these expressing cells derive. Based on extrapolation from the eve-expression pattern (Frasch et al. 1987), and the position of the cephalic furrow relative to the few cells stained in eve mutants, the $D f d$-expressing cells likely derive in part from the most anterior regions of the $D f d$ - 

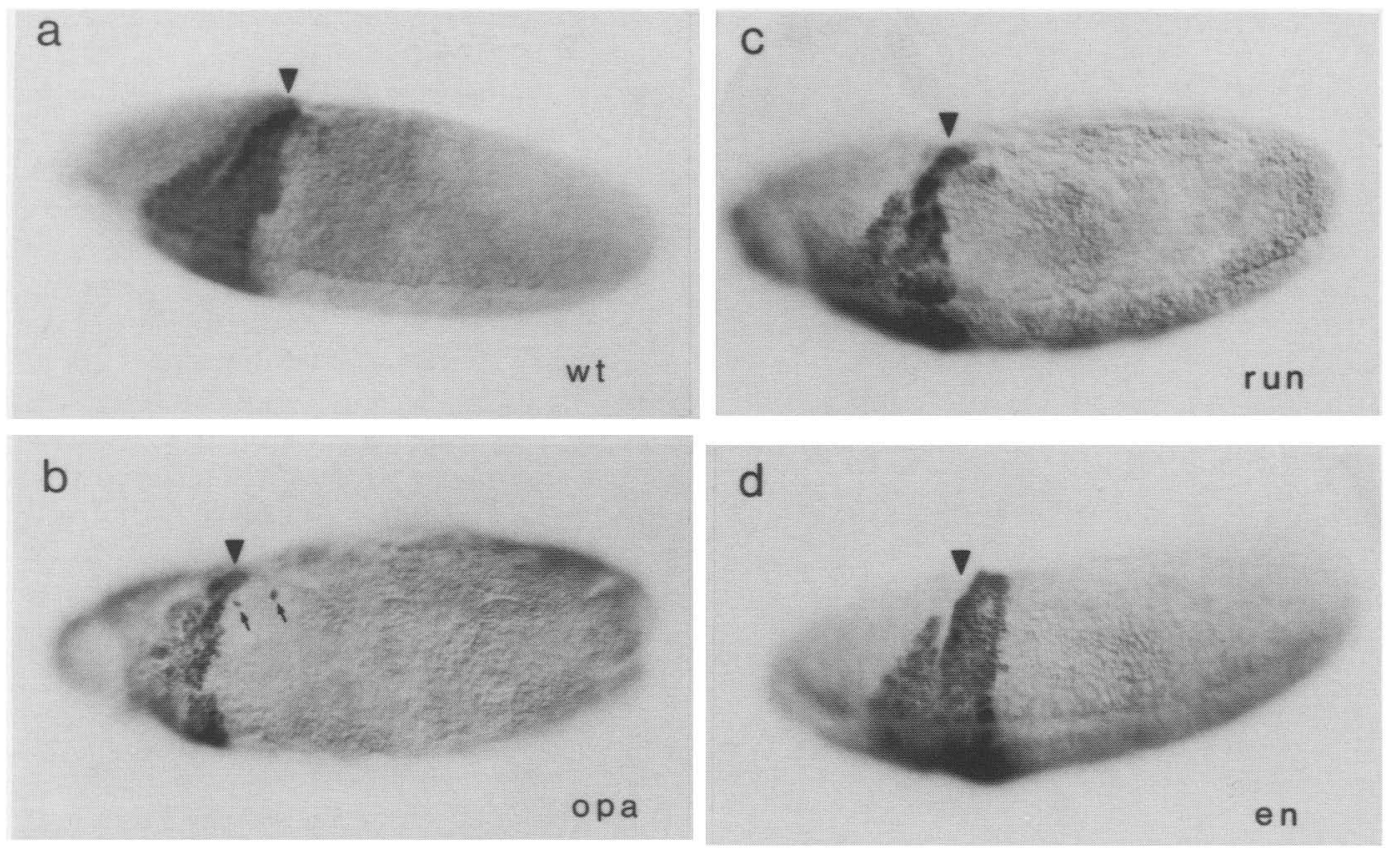

Figure 7. Expression of $D f d$ in opa, run, and en mutants. In all panels the anterior end of the embryo is to the left and the arrowhead marks the position of the cephalic furrow. (a) Ventrolateral view of a wild-type embryo at early germ band extension $(4.5 \mathrm{hr}$ AEL). ( $b$ ) Ventrolateral view of an opa- embryo at germ band extension. Note the reduction in Dfd expression in both lateral and ventral cells at the posterior boundary. In this embryo there are two or three isolated cells that express $D f d$ in the labial segment (arrows). (c) Ventrolateral view of a run- embryo. Dfd expression is reduced most drastically in the lateral cells that comprise the posterior boundary in wild-type embryos. (d) Ventrolateral view of an en- embryo. The reduction in $D f d$ expression is confined to the two rows of cells that extend posteriorly in lateral positions during early gastrulation in wild-type embryos.

expression pattern, with a few rows derived from the most posterior region (cells of the maxillary segment). The ventral-posterior extension of expression in eveappears similar to the pattern of misexpression observed in $f t z^{-}$embryos, and may be due to a lack of $f t z$ protein in this position in $e v e^{-}$embryos /Carroll and Scott 1986).

Homozygous embryos for weaker alleles of eve (e.g., $e v e^{3.77}$; eve $e^{I D} \mid$ exhibit the classic pair-rule phenotype, with alternate segment boundaries missing beginning with the maxillary-mandibular boundary. The $D f d$ expression in hypomorphic eve mutants is normal in lateral positions, but ventrally there are fewer expressing cells than in amorphic eve mutants. As with many of the amorphic eve embryos, there is a gap of nonexpressing cells between regions of expression (Fig. 8d). Ventrally, just posterior to the stomodeum, there are several expressing cells that are separated from the main cluster of $D f d$ expression by a gap of five or six cells. The clump of anterior cells corresponds in position to the progenitors of the hypopharyngeal or anterior mandibular segment while the posterior band of expression is in the position of the maxillary segment. In eve hypomorphs, the gap between the clusters of expressing cells is more pronounced and occurs in a higher percentage of the mutant animals, when compared to eve amorphs. The gap between regions of expression likely corresponds to the cells of the posterior mandibular and ante- rior maxillary segments, the cells that fail to develop normally in hypomorphic eve embryos.

paired (prd) The segment boundaries missing in prd are the same as those missing in $h$ and opposite those missing in $f t z$, run, and opa (see Fig. 3; Nüsslein-Volhard and Wieschaus 1980). At the synyctial blastoderm stage (13th nuclear division), prd is expressed as a broad band from 60 to $75 \%$ egg length (Kilchherr et al. 1986). At the 14th nuclear division this broad anterior stripe divides in two, with the anteriormost stripe slightly narrower than the six stripes more posterior. This most anterior prd stripe spans the mandibular-maxillary segment boundary, with the main region of expression in the precursor cells of the mandibular segment. When cellularization of the blastoderm is complete, cells in the middle of each of the prd-expression stripes, except the first, stop expressing prd. The first prd-expression stripe then narrows so that only the posteriormost cells of the stripe continue to exhibit prd transcript accumulation (Kilchherr et al. 1986).

In prd mutants, the pattern of $D f d$ expression appears normal in the maxillary segment and at the posterior boundary. In anterior cells, the $D f d$ protein is not expressed in a substantial part of the normal expression domain. Most of the cells of the mandibular and hypopharyngeal segments fail to express $D f d$ (Fig. $8 \mathrm{~b}$ ). In prd mutants, more cells express $D f d$ at the anterior border in 
ventral cells than in lateral cells; this is visualized as a cluster of cells that project slightly farther anteriorly along the ventral midline.

\section{Additive and independent effects via double and triple mutant combinations}

To test for the independence of some of the pair-rule regulatory effects on $D f d$ expression, we stained embryos carrying double- and triple-mutant combinations. In an odd prd $^{-}$double mutant, (Fig. 9a), the Dfd-expression pattern appears as the superimposition of the two single mutant patterns. That is, staining of anterior cells is missing as in prd $^{-}$, and the lateral posterior boundary of staining is extended as in odd ${ }^{-}$. If a hypomorphic eve allele is added to the odd ${ }^{-} \mathrm{prd}^{-}$double mutant to make a triple mutant, there are even fewer $D f d$-expressing cells. In the triple mutant odd $d^{-}$prd $^{-}$ $e v e^{-}$(Fig. 9b), one or two additional rows of cells along the ventral midline no longer stain when compared to the pattern seen in the odd $d^{-}$prd ${ }^{-}$double mutant. Likewise in $\mathrm{prd}^{-} \mathrm{opa}^{-}$the effects of the two mutants are additive. Single mutants in both prd and opa reduce the number of $D f d$-expressing cells, prd eliminating the anteriormost cells and opa eliminating the posteriormost cells of the wild-type pattern. Most, but not all of the $D f d$-expressing cells are eliminated by prd opa double mutants. At germ band extension ( $5 \mathrm{hr}$ AEL) in ventral positions there are only four or five patchy rows of $D f d$ expressing cells (Fig. 9c). There are even fewer expressing cells in prd opa mutants in lateral positions, with only one or two expressing rows. It is likely that the few cells that are expressing derive from the cells in the anteriormost positions of the maxillary segment where neither prd nor opa are expressed.

\section{Discussion}

We find that the expression of $D f d$ is negatively controlled primarily by the action of two pair-rule genes, odd and $f t z$, and positively controlled by the hierarchical and combinatorial action of six pair-rule genes, en, opa, eve, prd, run, and $f t z$. Our results also point to the probable existence of two other factors necessary to explain the activation of $D f d$ in the maxillary-mandibular region. One postulated positive factor /from either $h b$ or $b c d$, or possibly both) would be generally localized anterior to the labial-T1 region; this requirement could also be satisfied by a posterior-polar negative regulatory factor or factors. The other postulated factor would be expressed during gastrulation and differentially localized on the dorsal-ventral axis. Although many other factors may be necessary to control fine structure details in the $D f d$ pattern, we propose that many of the principal regulatory genes are those described above (shown schematically in Fig. 10).
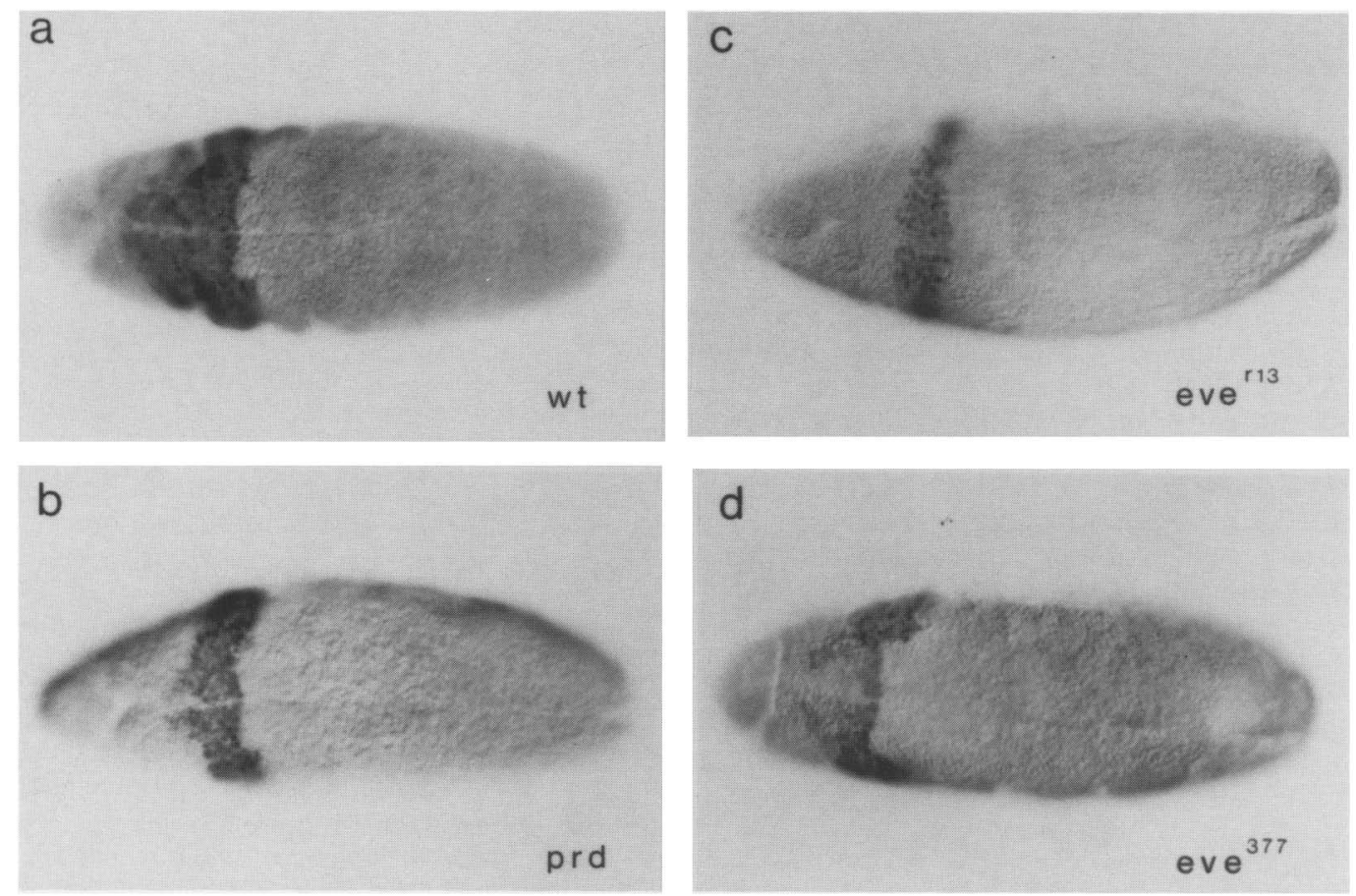

Figure 8. Expression of $D f d$ in prd and eve mutants. In all panels the anterior end of the embryo is to the left. (a) Ventral view of a stained wild-type embryo, just after the formation of the gnathal segment boundaries $(6 \mathrm{hr}$ AEL). (b) Ventral view of a prd mutant embryo. $D f d$ expression in cells that comprise the anterior portion of the wild-type expression pattern is missing. $(c)$ Ventral view of an $e v e^{r 13}$ embryo (amorphic allele). There is a drastic reduction in the number of $D f d$-expressing cells in both ventral and lateral positions. (d) Ventral view of an embryo containing the hypomorphic allele $e v e^{3.77}$. Notice the gap between regions of expression at the anterior and posterior boundaries along the ventral midline. 


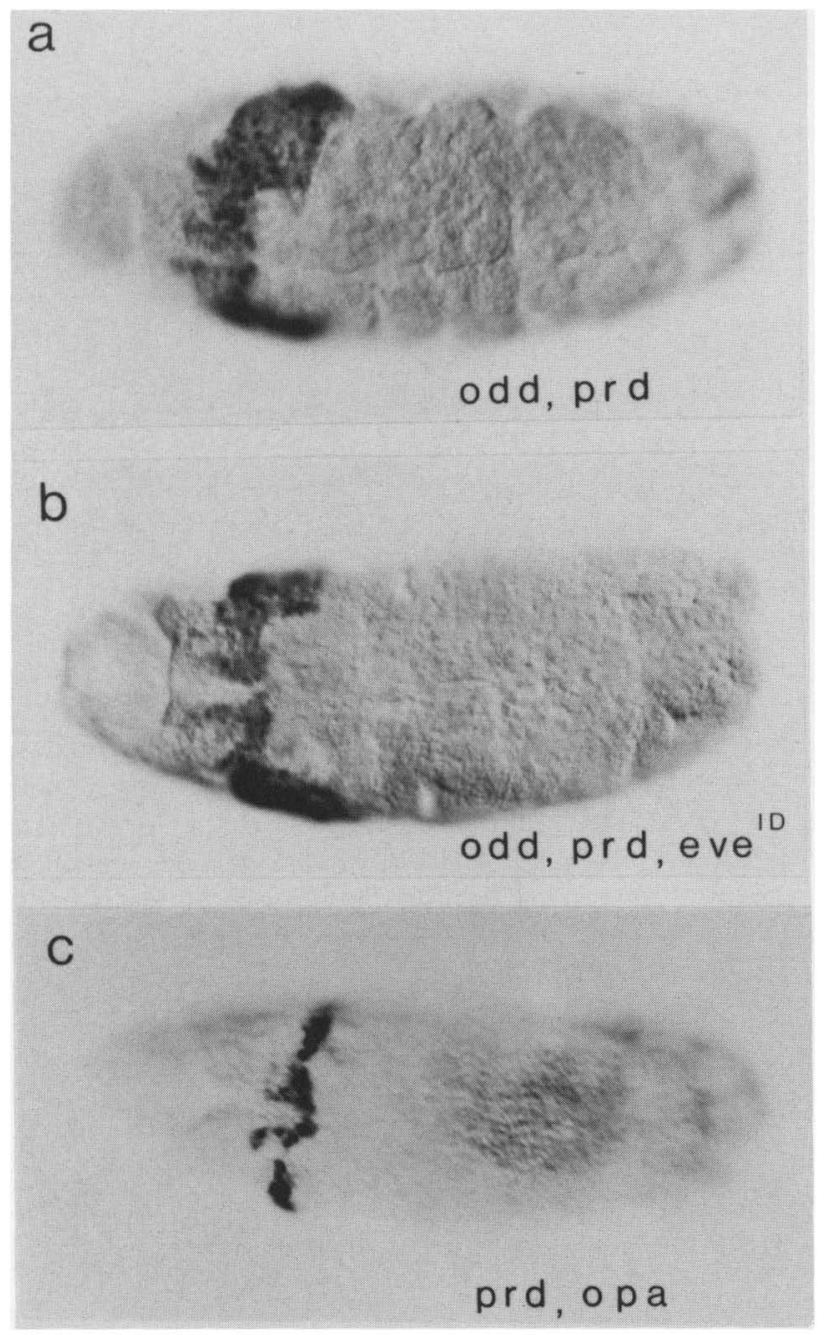

Figure 9. Expression of $D f d$ in double- and triple-mutant combinations of pair-rule genes. In all panels the anterior end of the embryo is to the left. $(a)$ Ventrolateral view of an embryo in the early stages of germ band retraction ( $8 \mathrm{hr}$ AEL) containing the double-mutant combination $\mathrm{prd}^{-}$odd ${ }^{-}$. The Dfd-expression pattern represents the additive nature of the two single mutant patterns; the lateral expression of $D f d$ is extended as in $o d d^{-}$(see Fig. 4b) and the ventral anterior cells fail to express as in prd $^{-}$(see Fig. 6a). (b) Ventral view of an embryo at the same stage as $(a)$ with the genotype $p r d^{-}$odd- $e v e^{\mathrm{DI} 19}$ (for wild-type comparison see Fig. $2 \mathrm{f}$ ). The addition of the eve mutant to the prd ${ }^{-}$odd $d^{-}$-double mutant results in the decrease in the expression of $D f d$ in the ventralmost cells of parasegment $1 .(c)$ Ventrolateral view of a germ band extended prd ${ }^{-}$opa ${ }^{-}$embryo (5 hr AEL). This double-mutant combination eliminates most of the expression in cells at both the anterior and posterior boundaries of the normal $D f d$-expression pattern.

\section{Patterns of Dfd protein accumulation during embryogenesis}

The principal early domains of $D f d$ protein expression are the mandibular and maxillary segments of the embryonic head. Very early in development, during gastrulation, the posterior boundary of $D f d$ expression, initially lying at the posterior boundary of parasegment 1 , shifts to respect simultaneously both segmental and parasegmental boundaries at the extended germ band stage. Other homeotic expression patterns are confined by both segmental and parasegmental boundaries, but not in such an early and obvious fashion as $D f d$. $S c r$, for example, is first expressed in parasegment 2; later Scr is expressed at high levels in the labial lobe and also in a few cells of the maxillary and T1 segments. The boundaries of $S c r$ do show a quantitative but not a qualitative distinction between segmental (or compartmental) and parasegmental limits. The simultaneous appearance of $D f d$ within both parasegmental and segmental boundaries suggests that the morphological determination of the head may 'speeded up' when compared with the development of the thorax and abdomen. Supporting this, in the posterior body regions (thorax and abdomen) the parasegmental grooves form at about $5 \mathrm{hr}$ AEL and segments are visible between 6.5 and $7 \mathrm{hr} A E L$, while in the head the gnathal lobes form at the same time as do the parasegmental grooves. Also consistent with this idea is the graded expression of the genes en and eve along the anterior-posterior axis, as the more anterior stripes appear before the expression stripes in more posterior body regions.

\section{Hierarchical control of Dfd expression}

The apparent dependence of $D f d$ on the pair-rule genes rather than the gap genes is consistent with a view of

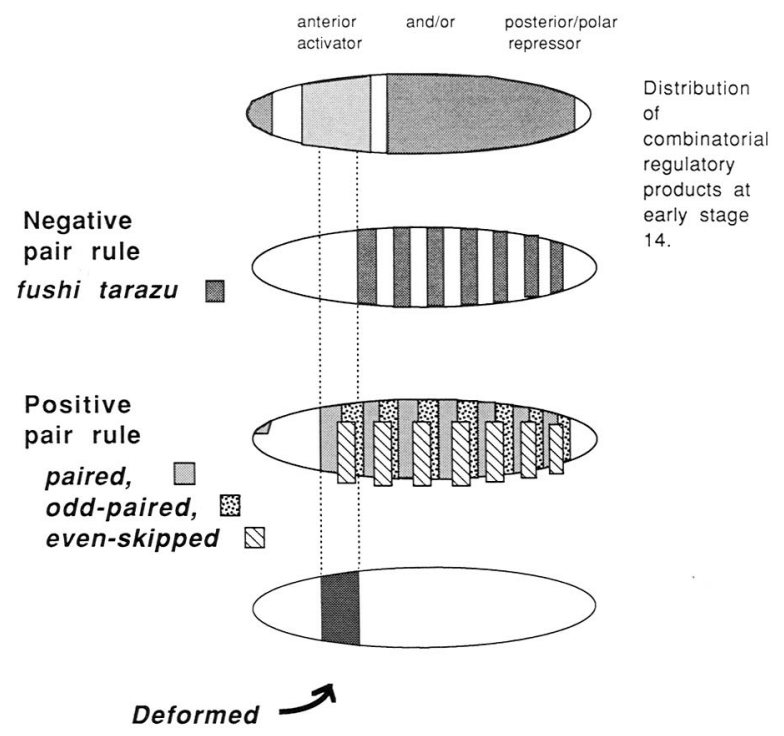

Figure 10. Summary of the postulated elements involved in the initiation of $D f d$ expression. Both postulated positive and negative factors involved in the establishment of $D f d$ expression are indicated in schematic embryos. We postulate that the pair-rule gene $f t z$ negatively regulates $D f d$ and defines the posterior boundary of $D f d$ expression. Combinations of the pairrule genes prd, opa, and eve are necessary to activate the initial stripe of $D f d$ expression. In addition, we postulate the existence of an anterior activator (possibly $h b$ or $b c d$ ) that acts in combination with the pair-rule genes and/or a posterior/polar repressor that prevents $D f d$ expression in other regions of the embryo. 
developmental control of selectors that is largely hierarchical. In a simple hierarchical model, it is expected that developmental signals flow from the maternal effect genes to zygotic gap genes to pair-rule genes, and finally to homeotic genes. The apparent requirement for more than one pair-rule product in a certain position could be due to a successive, interdependent hierarchy of genes that must be expressed in a certain cell, eventually focusing on a single factor that throws the on or off switch. Alternatively, these alterations could be due to a network of combinatorial interactions, in which the amounts of pair-rule products are sampled on a cell-bycell basis by $D f d$ regulatory sequences or factors, and in those cells which have the correct combination of factors, $D f d$ would be turned on. Of course, these two conceptual regulatory models are not mutually exclusive and we argue that the regulation of $D f d$ is a mixture of the above with evidence favoring a model in which many of the pair-rule genes act in a successive, interdependent fashion to control the expression of $D f d$.

The ability to distinguish combinatorial versus hierarchical effects of pair-rule mutation on selector expression depends to a large degree on the amount of crossregulation between the different genes of this class. Because not all pair-rule expression patterns have been analyzed, either in wild-type or other pair-rule mutant backgrounds, a complete picture cannot at present be drawn. However, some hierarchical relationships exist, as has been observed for the nonreciprocal alterations in the normal $\mathrm{ftz}$ and eve expression patterns in $h$ and run mutants (Carroll and Scott 1986; Howard and Ingham 1986; Frasch and Levine 1987).

Gap genes Our analysis of $D f d$ expression in the gap mutants $h b, g t$, and $k n$ indicates that the zygotic products of these genes are dispensable for a normal expression pattern. The subtle changes in the $D f d$ pattern in $K r$ mutants are likely indirect and due, at least in part, to subtle changes in $\mathrm{ftz}$ expression in $\mathrm{Kr}$ mutants (Carroll and Scott 1986). The lack of any changes in $\mathrm{kn} \mathrm{mu-}$ tants is not surprising, as this mutant is missing a block of abdominal segments. However, $h b$ and $g t$ mutants delete portions of the head. In strong $h b$ mutants the labial segment, all three thoracic segments, and posterior abdominal segments are missing. gt mutants are missing structures derived from the labial lobe as well as parts of the cephalopharyngeal skeleton (Gergen and Wieschaus 1986b|. The anlagen of these structures are fate mapped to locations more anterior and dorsal than the mandibular segment. Because both $g t$ and $h b$ mutants fail to eliminate the structures that $D f d$ specifies, it is again consistent that the $D f d$-expression pattern is not affected in these mutants. At this point no zygotic gap gene has been identified whose mutant phenotype involves a deletion of the maxillary and mandibular segments. Recently it has been reported (Lehmann and Nüsslein-Volhard 1987) that $h b$ has a maternal as well as a zygotic function. Embryos that lack both maternal and zygotic contributions of the $h b$ gene exhibit extreme phenotypes that are missing all gnathal segments, in- cluding the maxillary structures specified by $D f d$. Although we have not yet not tested the effect of this maternal contribution, it is likely that the presence of either the maternal or zygotic $h b$ product is sufficient for normal spatial expression of $D f d$, and the loss of both results in a lack of $D f d$ expression.

Homeotic selector genes Mutations in other homeotic selector genes of the ANT-C and BX-C, which are expressed in approximately the same time frame as $D f d$, and potentially act as regulators of the maintenance of proper $D f d$ spatial expression, had no effect on the maintenance of the $D f d$ pattern. Cross-regulatory interactions among the homeotic selector genes of the thorax and abdomen have been shown to be required for the correct maintenance (as opposed to initiation) of selector gene expression boundaries. For example, the normal posterior boundary of abundant and persistent Antp expression is in $\mathrm{T} 3$, but in embryos lacking the genes of the BX-C, Antp is persistently expressed as far posterior as $\mathrm{A} 8$, strongly suggesting that the $\mathrm{BX}-\mathrm{C}$ genes repress Antp expression in wild-type embryos (Struhl 1983; Hafen et al. 1984b; Harding et al. 1985). If $D f d$ were to fit this general rule then it would be predicted that in the absence of $S c r$ or other posteriorly expressed selector genes $D f d$ expression would spread posteriorly. However, in $S c r$ mutants (as well as $S c r^{-} A n t p^{-}$double mutants, and $S_{C r}-A n t p^{-}$BX-C ${ }^{-}$triple mutants), the $D f d$ pattern is normal. The maintenance of the posterior boundary of $D f d$ expression does not appear to be regulated by the homeotic genes of the thorax and abdomen, perhaps relying more on a auto-regulatory loop than on cross-regulation.

Pair-rule negative regulators Two of the pair-rule genes, $f t z$ and odd, appear to function in part to set the posterior limit of $D f d$ protein expression. $D f d$ expression expands posteriorly in both these mutants so this limitation appears to be controlled by negative regulation of $D f d$ in cells immediately adjacent to the normal $D f d$ expression domain. It seems that $f t z$ is more important in setting this limit in ventral cells, while odd is more important in lateral cells. Along the dorsal-ventral axis the boundary separating these two regions of control coincides with the division separating the segmental and parasegmental boundaries of $D f d$ expression seen in wild-type embryos.

This proposed role for $f t z$ as a negative regulator of $D f d$ is in sharp contrast to its effect on other homeotic genes, considering that $f t z$ is necessary to activate the early high-level expression of $S c r, A n t p$ and $U b x$ in parasegments 2, 4, and 6, respectively (Duncan 1986; Ingham and Martinez-Arias 1986; Martinez-Arias and White 1988). In wild-type embryos the first $f t z$ expression stripe is in the primordia of the cells of parasegment 2 (Martinez-Arias and Lawrence 1985; Lawrence et al. 1987). Along the ventral midline the posterior boundary of $D f d$ expression is the parasegment 1 -parasegment 2 boundary. Thus, the normal protein expression domains of $D f d$ and $f t z$ are mutually exclusive. In $f t z$ mutants 
$D f d$ is misexpressed in the ventral cells of what would normally be parasegment 2 , although not throughout the entire parasegmental domain. Thus, by the criterion of $D f d$ expression, the cells that normally give rise to parasegment 2 have not all been transformed into parasegment 1 . In fact the expression of the fused PS1-PS2 appears to be partitioned by expression of $D f d$ and $S c r ; D f d$ expressed roughly in the anterior half of the fused parasegment and Scr in the posterior half /cf., Fig. 4b with Fig. 4f from Riley et al. 1987). These results conflict with the conceptual view of $f t z$ function proposed by Ingham and Martinez-Arias (1986; see particularly Fig. 2) and Duncan (1986). In their view, the loss of $f t z$ function results in an embryo consisting of a string of double-wide, odd-numbered parasegments (or protosegments; Duncan 1986). The expression patterns of $D f d$ and $S c r$ in $f t z$ mutants do not support this view. Instead, the positive regulatory effect of $f t z$ on the selectors Antp and $U b x$ and the negative regulatory effect on $D f d$ is better explained by a cell autonomous effect of $f t z$ throughout its stable striped expression pattern. In this view $\mathrm{ftz}$ and the other pair-rule genes affect selector expression only in the regions of overlap between the pair-rule gene and the downstream selector. Thus, the regulatory activities of $f t z$ are not fundamentally different from the regulatory activities of the other pair-rule genes.

The effects of odd are confined to the lateral cells of the anterior labial segment where the odd product appears to prevent $D f d$ expression in wild-type embryos. Currently the molecular details of the expression pattern of odd are not known, but it is unlikely that odd is expressed only in lateral positions as odd mutants exhibit segmental deletions in ventral as well as lateral cells. The misexpression of $D f d$ in the anterior cells of the labial segment correlates with the misexpression of $e n$ in these same cells in odd mutants (DiNardo and O'Farrell 1987). The absence of odd and the presence of en are not sufficient to turn on $D f d$ in the lateral cells of the anterior labial segment. In addition another factor that is differentially distributed on the dorsal-ventral axis of the embryo is required. Perhaps this dorsal-ventral regulatory factor acts in conjunction with en to turn on $D f d$ in these lateral cells in the absence of the odd product (see following on positive regulators).

Pair-rule positive regulators At the posterior boundary of $D f d$ expression (the posterior region of the maxillary segment) on the lateral aspect of the embryo, the pairrule genes that are necessary for $D f d$ protein accumulation include eve, run, $f t z$, opa, and en. Considering the relatively late appearance of en protein in this region, and since mutations in eve, ftz, run, and opa (Harding et al. 1986; Howard and Ingham 1986; DiNardo and O'Farrell 1987; Martinez-Arias and White 1988) remove or abolish en expression in this region, it is likely that many of these regulatory effects are mediated through $e n$. Therefore, in the context of $D f d$ activation, it is possible that the en gene product functions directly as a positive regulator in this region, with the other pair-rule genes serving only to activate its expression in the poste- rior compartment of the maxillary segment. It is equally possible that one or more of the previously expressed pair-rule regulatory gene products serves both to activate $e n$ as well as to act in combination with it to activate $D f d$.

As mentioned earlier, in wild-type embryos these posterior maxillary cells begin expressing $D f d$ during the early stages of germ band extension (about $4 \mathrm{hr}$ AEL). At this stage the en protein is expressed in these same cells (DiNardo et al. 1985). The en protein is expressed later than the proteins of some other pair-rule genes. Although this is consistent with the lag in appearance of $D f d$ expression in the posterior-lateral maxillary cells, en is not sufficient for the expression of $D f d$ in these maxillary segment cells since it does not induce $D f d$ expression on the ventral aspect of the embryo. These observations suggest that an additional factor is necessary for the posterior-lateral expression of $D f d$ in the maxillary segment, and that this unknown factor is differentially active on the dorsal-ventral aspect of the embryo. This postulated factor would also serve to explain the apparent paradox of $f t z$ acting as both a positive and negative regulator at this position. On the lateral aspect of the embryo, this factor would be epistatic to the negative regulatory effect of $f t z$, and would allow en to positively regulate. As mentioned earlier, this same factor likely acts in combination with en to misexpress $D f d$ in the lateral cells of the labial segment in odd mutants.

In the anterior and central regions of the maxillary segment (central and posterior regions of parasegment 1) the gene products of run, opa, and eve are required to activate $D f d$ expression. All affect both ventral and lateral expression of $D f d$. Judging from the cells no longer expressing $D f d$ in run mutants, run is required only within the central region of the maxillary segment (the posterior edge of parasegment 1). In contrast opa is required in an overlapping region that extends a few cells more anteriorly, almost to the anterior boundary of the maxillary segment. It does not appear that eve is required in the central region of the maxillary segment, but is required even farther anteriorly than opa, in cells of the anterior maxillary segment and the posterior mandibular segment (see Fig. 3). In addition, prd is required to positively regulate $D f d$ protein accumulation in the mandibular region. Because the anterior boundary of $D f d$ expression is still farther anterior than the anterior limit of prd circumferential expression, it is likely that an as yet unidentified gene or genes activate $D f d$ in these anterior cells, and may act in combination with prd in the cells of the mandibular segment.

\section{Other factors necessary for control of Dfd expression}

Although the pair-rule genes as a class have a dramatic effect on the $D f d$ - expression pattern, pair-rule genes alone are not sufficient to explain the localization of $D f d$ in the maxillary and mandibular segments of the head. The genes with positive regulatory effects (en, run, opa, $f t z$, eve, and prdl, are expressed in combination throughout the thorax and abdomen. Thus at least one 
additional product is necessary to localize the $D f d$ regulatory effects of pair-rule genes to the head. This additional factor could consist of a head-specific activator localized anterior to the labial-T1 region which acts in concert with the previously described pair-rule genes. Alternatively, there may be a posteriorly expressed repressor or repressors, localized posteriorly and at the anterior pole, which prevent the positive pair-rule genes from acting in regions outside the head (see Fig. 10). There are at least two candidate gene products for a head specific positive regulator for $D f d$. The first is the maternally expressed product of the $h b$ gene, which is localized in a gradient initiating at the anterior pole (Tautz et al. 1987; Tautz 1988). The second possibility is represented by the products of the maternal effect gene, $b c d$, a gene whose activity and transcripts are concentrated in the head and anterior thoracic region (Frigerio et al. 1986; Frohnhofer and Nüsslein-Volhard 1986). Consistent with this latter possibility, $D f d$ is not expressed in bcd- embryos (unpubl.).

In addition to a factor (or factors) localized along the anterior-posterior axis, proper expression of $D f d$ likely requires a second factor differentially distributed along the dorsal-ventral axis. The effects of many of the pairrule genes on the $D f d$ pattern are localized to groups of cells in either ventral or lateral aspects of the embryo. For example, the effects of odd, en, and run are confined to lateral cells of the $D f d$ pattern while the primary effect of $f t z$ is in ventral cells. Because the pair-rule gene products are distributed in both lateral and ventral locations, a differentially localized dorsal-ventral factor likely interacts with the pair-rule genes to bring about further specification of cell identity.

We speculate that some of the products of these proposed regulatory genes may act directly to regulate $D f d$ transcription, as activators and repressors. Based on their known or suspected locations in the hierarchy of pairrule genes, and their time of expression relative to $D f d$, the most likely direct regulators are $f t z$ (negative) and prd, opa, and en (positive). Three of these four genes, $f t z$, prd, and en (Laughon and Scott 1984; McGinnis et al. 1984; Fjose et al. 1985; Poole et al. 1985; Bopp et al. 1986), are known to be homeobox genes; the molecular genetics and sequence of opa are as yet uncharacterized. Coupled with the increasing evidence that the homeodomain in its various manifestations has sequence-specific DNA-binding activity (Desplan et al. 1985; Hall and Johnson et al. 1987; Hoey et al. 1988), these results suggest that a hierarchy of homeobox regulatory genes play a large role in subdividing and determining the developmental pathways followed by cells during the early stages of Drosophila embryogenesis.

\section{Materials and methods}

Expression and purification of full-length Dfd protein and production of antibodies

To overproduce the $D f d$ protein we used the $T 7$ expression system. In the construction of pARDfd (Fig. 1a), a $1.8-\mathrm{kb}$ SacIEcoRV fragment from the Dfd cDNA plasmid pcDfd41 was cloned into the T7 expression vector pAR3040 cut with BamHI, filled in, and cut with NdeI. The SacI site in $D f d$ lies between the second and third amino acids; in order to get the full-length $D f d$ protein cloned into pAR3040, an eight-base oligonucleotide was cloned between the NdeI site of pAR3040 and the SacI site of $D f d$. The resulting plasmid, pAR $D f d$, was transformed into the strain BL21, a lysogen that contains a single copy of the T7 RNA polymerase gene under the control of the lac promoter (Studier and Moffat 1986). Upon induction with isopropyl $\beta-D$ thio-galactopyranoside (IPTG) (Sigma), amounts in the range of $5-10 \mathrm{mg} / \mathrm{l}$ of full-length $D f d$ protein were obtained. For injection into rabbits, the $D f d$ protein was purified using two different methods. For the initial injection, the full-length $D f d$ protein was cut out of an SDS-polyacrylamide gel and prepared as described previously (White and Wilcox 1984). A male New Zealand white rabbit was injected intradermally at about 50 sites (Vaitukaitis 1981) on day 0 with $200 \mu \mathrm{g}$ of $D f d$ protein in a 1:1 emulsion with Freund's complete adjuvant. The rabbit was boosted on day 34 with $75 \mu \mathrm{g}$ of $D f d$ protein purified in the presence of urea on ion exchange columns containing the resins P11 and DE52. For boosts, the protein was mixed $1: 2$ with Freund's incomplete adjuvant. On day 52 , the rabbit was bled, and yielded serum specific for $D f d$.

\section{Collection and staining of whole-mount embryos}

The $D f d$ serum used in the staining of whole-mount embryos was diluted $1: 75$, and immunoabsorbed with fixed, devitellinized 0-2 hr Drosophila embryos. Whole-mount embryo collection and fixation as well as antibody reactions were carried out as described previously (Karr and Alberts 1986; Frasch et al. 1987) with the following modifications for staining with antibodies conjugated to horseradish peroxidase (HRP). The secondary antibody was a biotinylated goat anti-rabbit IgG (Jackson Immunoresearch) preabsorbed against 0-12 hr embryos and diluted $1: 500$ to a concentration of $2 \mu \mathrm{g} / \mathrm{ml}$. After washing the nonspecifically bound secondary antibody, the embryos were treated with a 1:500 dilution of conjugated streptavidin-HRP (Enzo) for $1 \mathrm{hr}$ at $25^{\circ} \mathrm{C}$. The staining was carried out according to the protocol of MacDonald and Struhl (1986). After staining the embryos were dehydrated in $100 \%$ ethanol, rinsed with xylene, and mounted under a coverslip in Permount. Embryos were viewed with Nomarski interference optics and photographed with Kodak Technical Pan 2415 film.

\section{Acknowledgments}

We thank Eric Wieschaus, Janni Nüsslein-Volhard, Gary Struhl, Yash Hiromi, Jim Mahaffey, the Bowling Green Mid-America Drosophila Stock center, and the Levine lab for so generously supplying mutant stocks. We also thank Manfred Frasch for advice on antibody staining and Erich Frei for his help with protein purification and rabbit immunization. Also we are grateful to Markus Noll and Robin Chadwick for the communication of unpublished results. This research was supported by grants to W.M. from the National Research Foundation (NSF) and the Searle Scholar Fund.

\section{References}

Akam, M.E. 1983. The location of Ultrabithorax transcripts in Drosophila tissue section. EMBO J. 2: 2075-2084.

- 1987. The molecular basis for metameric pattern in the Drosophila embryo. Development 101: 1-22.

Beachy, P.A., S.L. Helfand, and D.S. Hogness. 1985. Segmental distribution of bithorax complex proteins during Drosophila development. Nature 313: 545-551.

Bopp, D., M. Burri, S. Baumgartner, G. Frigerio, and M. Noll. 1986. Conservation of a large protein domain in the seg- 
mentation gene paired and in functionally related genes of Drosophila. Cell 47: 1033-1040.

Campos-Ortega, J.A. and V. Hartenstein. 1985. The Embryonic development of Drosóphila melanogaster. Springer-Verlag, Berlin.

Carroll, S.B. and M.P. Scott. 1985. Localization of the fushi tarazu protein during Drosophila embryogenesis. Cell 43: 47-57.

-1986. Zygotically active genes that affect the spatial expression of the fushi tarazu segmentation gene during early Drosophila embryogenesis. Cell 45: 113-126.

Carroll, S.B., R.A. Layman, M.A. McCutcheon, P.D. Riley, and M.P. Scott. 1986. The localization and regulation of Antennapedia protein expression in Drosophila embryos. Cell 47: $113-122$.

Chadwick, R. and W. McGinnis. 1987. Temporal and spatial distribution of transcripts from the Deformed gene of Drosophila. EMBO I. 6: 779-789.

Desplan, C., J. Theis and P.H. O'Farrell. 1985. The Drosophila developmental gene, engrailed, encodes a sequence-specific DNA binding activity. Nature 318: 630-635.

DiNardo, S., J.M. Kuner, J. Theis, and P.H. O'Farrell. 1985. Development of embryonic pattern in $D$. melanogaster as revealed by accumulation of the nuclear engrailed protein. Cell 43: 59-69.

DiNardo, S. and P. O'Farrell. 1987. Establishment and refinement of segmental pattern in the Drosophila embryo: spatial control of engrailed expression by pair-rule genes. Gen. Dev. 1: 1212-1225.

Duncan, I. 1986. Control of bithorax complex functions by the segmentation gene fushi tarazu of D. melanogaster. Cell 47: 297-309.

Fjose, A., W. McGinnis, and W.J. Gehring. 1985. Isolation of a homeobox-containing gene from the engrailed region of Drosophila and the spatial distribution of its transcripts. Nature 313: 284-289.

Foe, V.E. and B.M. Alberts. 1983. Studies of nuclear and cytoplasmic behavior during the five mitotic cycles that precede gastrulation in Drosophila embryogenesis. I. Cell. Sci. 61: $31-70$.

Frasch, M., T. Hoey, C. Rushlow, H. Doyle, and M. Levine. 1987. Characterization and localization of the even-skipped protein of Drosophila. EMBO I. 6: 749-759.

Frasch, M. and M. Levine. 1987. Complimentary patterns of even-skipped and fushi tarazu expression involve their differential regulation by a common set of segmentation genes in Drosophila. Gen. Dev. 1: 981-995.

Frigerio, G., M. Burri, D. Bopp, S. Baumgartner and M. Noll. 1986. Structure of the segmentation gene paired and the Drosophila PRD gene set as part of a gene network. Cell 47: 735-746.

Frohnhofer, H.G. and C. Nüsslein-Volhard. 1986. Organization of anterior pattern in the Drosophila embryo by the maternal gene bicoid. Nature 324: 120-125.

Garcia-Bellido, A. 1977. Homeotic and atavic mutations in insects. Amer. Zool. 17: 613-629.

Gergen, J.P., D. Coulter, and E. Wieschaus. 1986. Segmental pattern and blastoderm cell identities. In Gametogenesis and the early embryo. Alan R. Liss, New York, pp. 195-220.

Gergen, J.P., and E. Wieschaus. 1986a. Dosage requirements for runt in the segmentation of Drosophila embryos. Cell 45: $289-299$.

-1986b. Localized requirements for gene activity in segmentation of Drosophila embryos; analysis of armadillo, fused, giant, and unpaired mutations in mosaic embryos. Wilhelm Roux's Arch. Dev. Biol. 195: 49-62.

Hafen, E., M. Levine, R.L. Garber, and W.J. Gehring. 1983. An improved in situ hybridization methods for the detection of cellular RNAs in Drosophila tissue sections and its application for localizing transcripts of the homeotic Antennapedia gene complex. EMBO I. 2: 617-623.

Hafen, E., A. Kuroiwa, and W.J. Gehring. 1984a. Spatial distribution of transcripts from the segmentation gene fushi tarazu during Drosophila embryonic development. Cell 37: 833-841.

Hafen, E., M. Levine, and W.J. Gehring. 1984b. Regulation of Antennapedia transcript distribution by the bithorax complex in Drosophila. Nature 307: 287-289.

Hall, M.N. and A.D. Johnson. 1987. Homeo domain of the yeast repressor alpha 2 is a sequence specific DNA-binding domain but is not sufficient for repression. Science 237: 10071012.

Harding, K., C. Wedeen, W. McGinnis, and M. Levine. 1985. Spatially regulated expression of homeotic genes in Drosophila. Science 229: 1236-1242.

Harding, K., C. Rushlow, H.J. Doyle, T. Hoey, and M. Levine. 1986. Cross-regulatory interactions among pair-rule genes in Drosophila. Science 233, 953-959.

Harding, K., and M. Levine. 1988. Gap genes define the limits of Antennapedia and Bithorax gene expression during early development in Drosophila. EMBO /. 7: 205-214.

Hazelrigg, T., and T.C. Kaufman. 1983. Revertants of dominant mutations associated with the Antennapedia gene complex of Drosophila melanogaster: Cytology and genetics. Genetics 105: 581-600.

Hoey, T. and M. Levine. 1988. Divergent homeo box proteins recognize similar DNA sequences in Drosophila. Nature 332: $858-861$.

Howard, K., and P. Ingham, P. 1986. Regulatory interactions between the segmentation genes fushi tarazu, hairy, and engrailed in the Drosophila blastoderm. Cell 44: 949-957.

Ingham, P.W., K.R. Howard, and D. Ish-Horowicz. 1985. Transcription pattern of the Drosophila segmentation gene hairy. Nature 318: 439-445.

Ingham, P.W., and A. Martinez-Arias. 1986. The correct activation of Antennapedia and bithoraz complex genes requires the fushi tarazu gene. Nature 324: 592-597.

Jackle, H., D. Tautz, R. Schuh, E. Seifert, R. Lehmann. 1986. Cross-regulatory interactions among gap genes of Drosophila. Nature 324: 668-670.

Jurgens, G., E. Wieschaus, C. Nusslein-Volhard, and H. Kluding. 1984. Mutations affecting the pattern of the larval cuticle in Drosophila melanogaster. II. Zygotic loci on the third chromosome. Wilhelm Roux's Arch. Dev. Biol. 193: 283-295.

Jurgens, G., R. Lehmann, M. Schardin, and C. Nusslein-Volhard. 1986. Segmental organization of the head in the embryo of Drosophila melanogaster. Wilhelm Roux's Arch. Dev. Biol. 195: 359-377.

Karr, T.L. and B.M. Alberts. 1986. Organization of the cytoskeleton of early Drosophila embryos. J. Cell Biol. 102: 14891504.

Kilchherr, F., S. Baumgartner, D. Bopp, E. Frei, and M. Noll. 1986. Isolation of the paired gene of Drosophila and its spatial expression during embryogenesis. Nature 321: 493-499.

Knipple, D.C., E. Seifert, U.B. Rosenberg, A. Preiss, and H. Jackle. 1985. Spatial and temporal patterns of Kruppel gene expression in early Drosophila embryos. Nature 317: 4044.

Kornberg, T. 1981. engrailed: a gene controlling compartment and segment formation in Drosophila Proc. Natl. Acad. Sci. 78: 1095-1099.

Kornberg, T., I. Siden, P. O'Farrell, and M. Simon. 1985. The engrailed locus of Drosophila: In situ localization of tran- 
scripts reveals compartment-specific expression. Cell 40: $45-53$.

Laughon, A. and M.P. Scott. 1984. Sequence of Drosophila segmentation gene: Protein structure homology with DNAbinding proteins. Nature 310: $25-31$.

Lawrence, P.A., P. Johnston, P. MacDonald, and G. Struhl. 1987. Borders of parasegments in Drosophila embryos are delimited by the fushi tarazu and even-skipped genes. $\mathrm{Na}$ ture 328: 440-442.

Lehmann, R., and C. Nüsslein-Volhard. 1987. hunchback, a gene required for segmentation of an anterior and posterior region of the Drosophila embryo. Dev. Biol. 119: 402-417.

Levine, M., E. Hafen, R.L. Garber, and W.J. Gehring. 1983. Spatial distribution of Antennapedia transcripts during Drosophila development. EMBO J. 2 :2037-2046.

Lewis, E.B. 1978. A gene complex controlling segmentation in Drosophila. Nature 276: 565-570.

MacDonald, P.M. and G. Struhl. 1986. Molecular gradient in early Drosophila embryos and its role in specifying the body pattern. Nature 324: 537-545.

MacDonald, P.M., P. Ingham, and G. Struhl. 1986. Isolation, structure and expression of even-skipped: A second pairrule gene of Drosophila containing a homeo box. Cell 470: $721-734$.

Mahaffey, J.W., and T.C. Kaufman. 1987. Distribution of the Sex combs reduced gene products in Drosophila melanogaster. Genetics 117: 51-60.

Martinez-Arias, A. and P.A. Lawrence. 1985. Parasegments and compartments in the Drosophila embryo. Nature 313: 639642.

Martinez-Arias, A., P.W. Ingham, M.P. Scott, and M.E. Akam. 1987. The spatial and temporal deployment of $D f d$ and $S c r$ transcripts during development of Drosophila. Development. 100: 673-680.

Martinez-Arias, A. and R.A.H. White. 1988. Ultrabithorax and engrailed expression in Drosophila embryos mutant for segmentation genes of the pair-rule class. Development 102: 325-338.

McGinnis, W., R.L. Garber, J. Wirz, A. Kuroiwa, and W.J. Gehring. 1984. A homologous protein-coding sequence in Drosophila homeotic genes and its conservation in other metazoans. Cell 37: 403-408.

Merrill, V.K.L., F.R. Turner, and T.C. Kaufman. 1987. A genetic and developmental analysis of mutations in the Deformed locus in Drosophila melanogaster. Dev. Biol. 122: 370-395.

Morata, G., and P.A. Lawrence. 1975. Control of compartment development by the engrailed gene in Drosophila. Nature 255: 614-617.

Nüsslein-Volhard, C., and E. Weischaus 1980. Mutations affecting segment number and polarity in Drosophila. Nature 287: 795-801.

Nüsslein-Volhard, C., E. Wieschaus, and G. Jurgens, 1982. Segmentation in Drosophila, a genetic analysis. Verh. Dtsch. Zool. Ges.1982: 91-104.

Nüsslein-Volhard, C., E. Wieschaus, and H. Kluding, 1984. Mutations affecting the pattern of the larval cuticle in Drosophila melanogaster. I. Zygotic loci on the second chromosome. Wilhelm Roux's Arch. Dev. Biol. 193: 267-282.

Nüsslein-Volhard, C., H. Kluding, and G. Jurgens. 1985. Genes affecting the segmental subdivision of the Drosophila embryo. Cold Spring Harbor Symp. Quant. Biol. 50: 145-154.

Poole, S.J., L.M. Kauvar, B. Drees, and T. Kornberg. 1985. The engrailed locus of Drosophila: Structural analysis of an embryonic transcript. Cell 40: 37-43.

Regulski, M., K. Harding, R. Kostriken, F. Karch, M. Levine, and W. McGinnis. 1985. Homeo box genes of the Antennapedia and Bithorax complexes of Drosophila. Cell 43: 7180.
Regulski, M., N. McGinnis, R. Chadwick, and W. McGinnis. 1987. Developmental and molecular analysis of Deformed: A homeotic gene controlling Drosophila head development. EMBO J. 6: 767-777.

Riley, P.D., S.B. Carroll, and M.P. Scott. 1987. The expression and regulation of Sex combs reduced protein in Drosophila embryos. Gen. Dev. 1: 716-730.

Schneuwly, S., A. Kuroiwa, and W.J. Gehring. 1987. Molecular analysis of the dominant homeotic Antennapedia phenotype. $E M B O$ J. 6: 210-206.

Scott, M.P., and P.H. O'Farrell. 1986. Spatial programming of gene expression in early Drosophila embryogenesis. Ann. Rev. Cell. Biol. 2: 49-80.

Scott, M.P., and S.B. Carroll. 1987. The segmentation and homeotic gene network in early Drosophila development. Cell 51: 689-698.

Shine, J., and L. Dalgarno. 1974. The 3 '-terminal sequence of Escherichia coli $16 \mathrm{~S}$ ribosomal RNA: complementarity to nonsense triplets and ribosome binding sites. Proc. Natl. Acad. Sci. 71: 1342-1346.

Steitz, J.A., and K. Jakes. 1975. How ribosomes select initiator regions in mRNA: base pair formation between the $3^{\prime}$ terminus of 16S RNA and the mRNA during initiation of protein synthesis in Escherichia coli. Proc. Natl. Acad. Sci. 72: 4734-4738.

Struhl, G. 1982. Genes controlling segmental specification in the Drosophila thorax. Proc. Nat1. Acad. Sci. 79: 73807384.

- 1983. Role of the $\mathrm{esc}^{+}$gene product in ensuring the selective expression of segment specific homeotic genes in Drosophila. J. Embryol. Exp Morph. 76: 297-331.

Studier, F.W. and B.A. Moffatt. 1986. Use of bacteriophage T7 RNA polymerase to direct selective high-level expression of cloned genes. J. Mol. Biol. 189: 113-130.

Tautz, D., R. Lehmann, H. Schnurch, R. Schuh, E. Seifert, A. Kienlin K. Jones, and H. Jackle. 1987. Finger protein of novel structure encoded by hunchback, a second member of the gap class of Drosophila segmentation genes. Nature 327: 383-389.

Tautz, D. 1988. Regulation of the Drosophila segmentation gene hunchback by two maternal morphogenetic centers. Nature 332: 281-284.

Vaitukaitis, J.L. 1981. Production of antisera with small doses of immunogen: multiple intradermal injections. Methods Enzymol. 73: 46-52.

Wakimoto, B.T. and T.C. Kaufman. 1981. Analysis of larval segmentation in lethal genotypes associated with the Antennapedia gene complex in Drosophila melanogaster. Dev. Biol. 81: 51-64.

Wakimoto, B.T., F.R. Turner, and T.C. Kaufman. 1984. Defects in embryogenesis in mutants associated with the Antennapedia gene complex of Drosophila melanogaster. Dev. Biol. 102: $147-172$.

White, R.A.H. and M. Wilcox. 1984. Protein products of the bithorax complex in Drosophila. Cell 39: 163-171.

-1985. Regulation of the distribution of Ultrabithorax proteins in Drosophila. Nature 318: 563-566.

White, R.A.H. and R. Lehmann. 1986. A gap gene, hunchback, regulates the spatial expression of Ultrabithorax. Cell 47: $311-321$.

Wirz, J., L.I. Fessler, and W.J. Gehring. 1986. The localization of the Antennapedia protein in Drosophila embryos and imaginal discs. $E M B O$ J. 5: 3327-3334.

Zalokar, M., and I. Erk. 1976. Division and migration of nuclei during early embryogenesis of Drosophila melanogaster. J. Microbiol. Cell. 25: 97-106. 


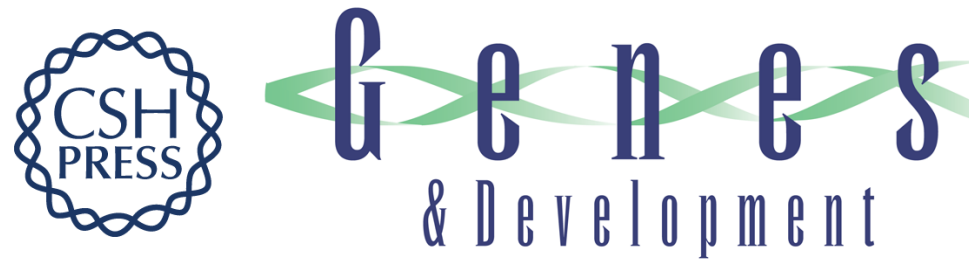

\section{Pair--rule segmentation genes regulate the expression of the homeotic selector gene, Deformed}

Genes Dev. 1988, 2:

Access the most recent version at doi:10.1101/gad.2.6.635

References This article cites 81 articles, 16 of which can be accessed free at: http://genesdev.cshlp.org/content/2/6/635.full.html\#ref-list-1

License

Email Alerting Receive free email alerts when new articles cite this article - sign up in the box at the top Service right corner of the article or click here.

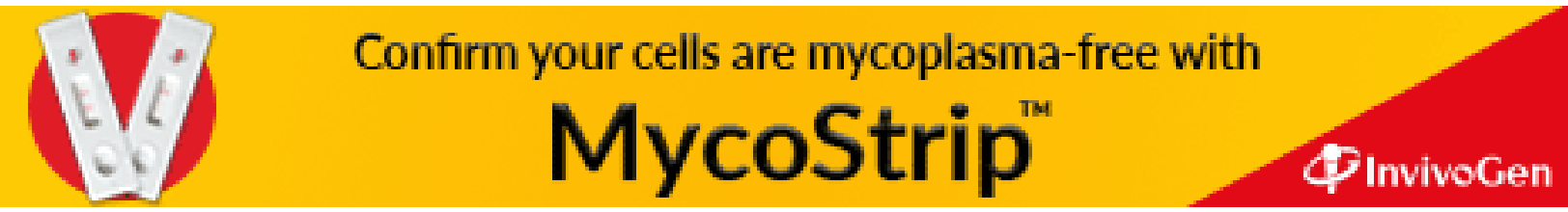

